\title{
Reforme zakonske zaštite zaposlenja $i$ ishodi na tržištu rada u Hrvatskoj
}

\section{Tomić, Iva}

Source / Izvornik: Odabrani prijevodi, 2020, 11, 1 - 35

Journal article, Published version

Rad u časopisu, Objavljena verzija rada (izdavačev PDF)

https://doi.org/10.3326/op.53

Permanent link / Trajna poveznica: https:/urn.nsk.hr/urn:nbn:hr:242:910647

Rights / Prava: Attribution-NonCommercial-NoDerivatives 4.0 International/ImenovanjeNekomercijalno-Bez prerada 4.0 međunarodna

Download date / Datum preuzimanja: 2023-04-26

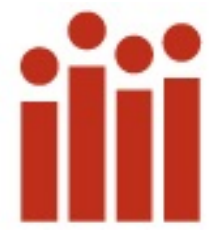

Institute of Public Finance Repository

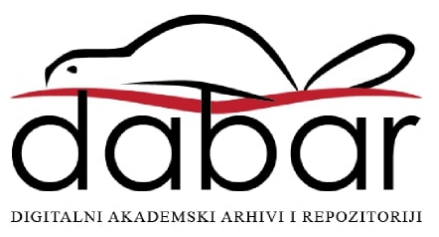




\section{REFORME ZAKONSKE ZAŠTITE ZAPOSLENJA I ISHODI NA TRŽIŠTU RADA U HRVATSKOJ}

ODABRANI

\section{PRIJEVODI}

\section{BR. 53}

\section{0.}

ISSN: $1847-7445$

doi: $10.3326 /$ op

\section{citirati:}

Tomić, I., 2020. Employment protection reforms and labour market outcomes in the aftermath of the recession: Evidence from Croatia. Public Sector Economics, 44 (1), str. 3-39.

https://doi.org/10.3326.pse.44.1.1
DR. sc. IVA TOMIĆ*

\author{
IZVORNI ZNANSTVENI ČLANAK ** \\ JEL: J21, J88, D04, C35 \\ DOI: $10.3326 /$ OP.53
}

\section{SAŽETAK}

U radu se analiziraju učinci reforme zakonodavstva o zaštiti zaposlenja na tržište rada u Hrvatskoj koristeći teorijske pretpostavke o parcijalnim reformama tržišta rada iz literature. Uz 'poticaj' zbog pristupanja EU, reforme su, pred kraj šestogodišnje recesije, liberalizirale odredbe o zaštiti zaposlenja i za ugovore na određeno (2013.) i na neodređeno (2014.), čineći tako jedinstven slučaj za evaluaciju javnih politika. Koristeći podatke Ankete o radnoj snazi u razdoblju 2007. - 2017. i primjenjujući metodu studije događaja (engl. event study) u kombinaciji s binarnim regresijama vjerojatnosti (engl. probit regressions), glavni nalazi sugeriraju da su reforme zaštite zaposlenja iz 2013. i 2014. dovele do porasta privremenog zapošljavanja, dok su učinci na ukupnu zaposlenost jasno vidljivi samo nakon druge reforme. Nadalje, rezultati probit regresije pokazuju da određene skupine stanovništva - žene, mladi, stranci, niskokvalificirani i samci iz ruralnih područja - imaju veću vjerojatnost da će završiti na poslovima s ugovorima na određeno, što upućuje na postojanje segmentacije na hrvatskom tržištu rada.

Ključne riječi: (ne)zaposlenost, zdravlje, starija radna dob, SHARE, Hrvatska

\footnotetext{
* Autorica zahvaljuje kolegama Valeriji Botrić, Marini Kunovac, Ivici Rubilu i Ivanu Žiliću te sudionicima konferencije LSEE Workshop on Economics of the Western Balkans i dvoje anonimnih recenzenata na korisnim raspravama i vrijednim komentarima koji su pomogli unaprijediti rad. Ovaj rad je djelomično financiran projektima ZAMAH (HR.3.2.01-0136) i Tvoj Grant@EIZ.

** Primljeno: 1. lipnja 2019.

Prihvaćeno: 13. studenoga 2019.
}

Rad je osvojio godišnju nagradu u redovitoj kategoriji „Zaklade prof. dr. Marijan Hanžeković" za 2019.

\section{Iva TOMIĆ}

Ekonomski institut, Zagreb, Odjel za tržište rada i socijalnu politiku, Trg J. F. Kennedyja 7,10000

Zagreb, Hrvatska

e-mail: itomic@eizg.hr

ORCiD: 0000-0002-4706-7881 


\section{UvOD}

Ublažavanje zakonske zaštite zaposlenja već se dugo zagovara kao način borbe protiv visoke nezaposlenosti, posebice u europskim zemljama. Međutim, empirijski dokazi o učincima fleksibilizacije radnog zakonodavstva na povećanje ukupne zaposlenosti nisu sasvim uvjerljivi. Jedan od razloga može biti i što se fleksibilizacija ili liberalizacija odvija na margini, odnosno, većina reformi zakonske zaštite zaposlenja ublažava ograničenja za ugovore na određeno, dok se ograničenja kod ugovora na neodređeno uglavnom ne mijenjaju. To dovodi do neravnoteže na tržištu rada jer su poslodavci motiviraniji zaposlenike s ugovorima na određeno zamijeniti za one s ugovorima na neodređeno, pritom stvarajući takozvano dualno tržište rada.

Iako se na privremeno zapošljavanje, odnosno na zapošljavanje preko ugovora na određeno, često gleda kao na prirodan način ulaska na tržište rada - ili kao na korak prema stalnom zaposlenju ali i kao način za poticanje otvaranja novih radnih mjesta i smanjenje nezaposlenosti, i teorijska i empirijska literatura pokazuju da to nije nužno slučaj. Naime, u praksi se, umjesto navedenoga, ugovori na neodređeno često zamjenjuju privremenim zapošljavanjem, čime se povećava fluktuacija radnika te čak dolazi do porasta nezaposlenosti (Blanchard i Landier, 2002.; Kahn, 2010.; Sala, Silva i Toledo, 2012.; Tejada, 2017.). Uz to, čini se da učestalije privremeno zapošljavanje smanjuje produktivnost rada i ukupno blagostanje (Blanchard i Landier, 2002.; Cahuc i Postel-Vinay, 2002.; Cahuc, Charlot i Malherbet, 2016.; Hijzen, Mondauto i Scarpetta, 2017.). S druge strane, u literaturi je jasno pokazano da određene skupine radnika - uključujući žene, mlade, manje obrazovane i manje kvalificirane radnike - češće rade s privremenim ugovorima (Kahn, 2007.). Pokazalo se i da su privremeni poslovi slabije plaćeni i nude manje osposobljavanja na radnom mjestu, dok su oni koji rade na tim poslovima u načelu manje zadovoljni (Blanchard i Landier, 2002.; Booth, Francesconi i Frank, 2002a; Barbieri i Cutuli, 2018.).

U literaturi postoji mnoštvo dokaza o negativnim učincima parcijalnih ili dualnih reformi na tržištu rada za razvijene zemlje; međutim, empirijske analize za istočnoeuropske zemlje i druge zemlje u razvoju još uvijek su prilično rijetke. To posebno vrijedi za Hrvatsku. Iako postoje neki radovi koji hrvatsko tržište rada kategoriziraju kao dualno (primjerice, Franičević, 2011.; Brkić, 2015.), pa čak i neki koji pokušavaju empirijski procijeniti utjecaj zakonodavstva o zaštiti zaposlenja na tržište rada (Tomić i Domadenik, 2012.; Matković, 2013.), ne postoje jasne analize izravnog utjecaja nedavnih reformi radnog zakonodavstva na hrvatsko tržište rada. Slijedom toga, cilj je ovoga rada otkriti moguće učinke tih reformi na tržište rada u Hrvatskoj. Primjenom regresijskih modela vjerojatnosti (engl. probit regression models) i studije događaja (engl. event study) na mikro podatke Ankete o radnoj snazi (ARS) u razdoblju između 2007. i 2017. nastoji se pokazati jesu li reforme radnog zakonodavstva iz 2013. i 2014. povećale učestalost privremenih ugovora o radu, odnosno ugovora na određeno vrijeme. Kako je moguće da su provedene reforme u potpunosti egzogeno određene potrebom usklađivanja hrvatskih propisa s onima u EU, ova analiza predstavlja jedinstven primjer evaluacije javnih politika. Budući da su obje reforme imale za cilj fleksibilizaciju zaštite zaposlenja, istražuje se i njihov utjecaj na cjelokupnu zaposlenost.

Hrvatska je zanimljiva za analizu iz više razloga. Kao prvo, zaštita zaposlenja u Hrvatskoj se smatra pretjerano rigidnom gotovo u cijelom razdoblju nakon procesa tranzicije, a često i glavnim krivcem za prilično nedinamično tržište rada. Drugo, recesija je u Hrvatskoj trajala punih šest godina te je 
otkrila brojne slabosti i samog tržišta rada, uključujući rigidnost plaća, budući da je prilagodba u krizi uglavnom provedena smanjivanjem zaposlenosti. Treće, pristupanje EU dogodilo se usred recesije i zapravo dovelo i do promjena, između ostalog, samog radnog zakonodavstva. U lipnju 2013. liberalizirane su odredbe vezane za zapošljavanje na određeno (privremene ugovore) te odredbe kojima se reguliraju kolektivna otpuštanja, dok je u srpnju 2014. novi zakon liberalizirao odredbe o zapošljavanju na neodređeno (stalne ugovore). Konačno, i druge značajke hrvatskog gospodarstva, poput sezonskog karaktera ili velikog javnog sektora, dodatno čine analizu utjecaja promjena radnog zakonodavstva na tržište rada vrijednom razmatranja.

Doprinos ovog rada je višestruk. Prvo, dostupna teorijska predviđanja o utjecaju dualnih reformi radnog zakonodavstva na tržišta rada empirijski su testirana na novoj zemlji koja ima neke specifične značajke koje nisu bile dostupne u prethodnim studijama. Drugo, koliko je poznato, ovo je prvi put da se metoda studije događaja primjenjuje na analizu utjecaja reforme radnog zakonodavstva na tržište rada. Modeli studije događaja češće se koriste u financijskoj ekonometriji, a tek odnedavno literatura iz primijenjene mikroekonomije ih koristi $u$ analizi učinaka reformi politika na tržište rada i blagostanje (primjerice, Simon, 2016.; Fuest, Peichl i Siegloch, 2018.; PerezTruglia, 2019.); međutim, ne i u studijama o reformama radnog zakonodavstva. Nadalje, budući da vođenje politike temeljene na dokazima nije karakteristično za Hrvatsku, ali i s obzirom na to da su s pristupanjem EU bile potrebne brojne izmjene različitih zakonskih odredbi, ovaj rad daje vrijedan doprinos domaćoj literaturi o evaluaciji javnih politika. Konačno, budući da se pristupanje EU nije samo poklopilo s reformama, nego je poslužilo i kao „poticajni čimbenik“ za postizanje liberalizacije radnog zakonodavstva, dobiveni rezultati za Hrvatsku mogu biti korisni i za zemlje kandidatkinje i buduće pristupnice EU.

Ostatak rada je organiziran na sljedeći način. Sljedeće poglavlje ukratko razmatra relevantne studije koje pokrivaju glavna pitanja učinaka radnog zakonodavstva - posebice parcijalnih reformi zakonodavstva o zaštiti zaposlenja - na tržište rada u Europi. Poglavlje se dotiče i nekih radova povezanih sa segmentacijom na hrvatskom tržištu rada, dok se u poglavlju nakon toga detaljnije opisuje samo tržište rada i institucionalni kontekst u Hrvatskoj, s fokusom na razdoblje između 2007. i 2017. Četvrto poglavlje daje opis korištenih podataka i glavne empirijske strategije, raspravljajući o mogućim nedostacima i načinima kako se s njima nositi uzimajući u obzir dostupne nalaze iz literature. Peti dio prikazuje glavne rezultate, uključujući analizu studije događaja i procjene regresije vjerojatnosti (probit) s analizama osjetljivosti unutar kojih se ocjenjuje nekoliko različitih specifikacija modela kako bi se dodatno potvrdili dobiveni rezultati i testirala robusnost predstavljenih modela. Zaključni dio daje kratki sažetak glavnih nalaza i nastavlja raspravu o nekim ograničenjima rada s prijedlozima za buduća istraživanja.

\section{Pregled literature}

Utjecaj zakonske zaštite zaposlenja na ishode na tržištima rada privukao je veliku pozornost u ekonomskoj literaturi. Ranije studije visoku zaštitu zaposlenja drže glavnim razlogom visoke nezaposlenosti u Europi, posebice u usporedbi s SAD-om (primjerice, Nickell, 1997. ili Siebert, 1997.). Međutim, negativni učinci rigidnog radnog zakonodavstva na (ne)zaposlenost zapravo nikada nisu u potpunosti potvrđeni (Piton i Rycx, 2018.; Bentolila, Dolado i Jimeno, 2019.), budući da stroga zaštita zaposlenja ne samo da smanjuje stopu zatvaranja radnih mjesta (engl. job 
destruction rate), nego i - zbog očekivanih budućih troškova otpuštanja - smanjuje stopu otvaranja novih radnih mjesta (engl. job creation rate), čime možda uopće ne mijenja ili čak povećava razinu nezaposlenosti. Ipak, mnoge su europske zemlje pokušale dinamizirati svoja tržišta rada liberalizacijom radnog zakonodavstva.

Međutim, većina tih zemalja pristupila je problemu visoke nezaposlenosti i rigidnog radnog zakonodavstva olakšavši samo one odredbe koje se odnose na privremeno zapošljavanje (ugovore na određeno), dok su ograničenja koja se odnose na ugovore na neodređeno ostala uglavnom nepromijenjena (Bentolila, Dolado i Jimeno, 2019.). Odnosno, europske su zemlje provele reformu 'na margini' ili su uvele takozvanu selektivnu fleksibilnost (Blossfeld i sur., 2012.; Barbieri i Cutuli, 2015.). To je stvorilo podjele između tzv. insajdera i autsajdera na tržištu rada (Eichhorst i Marx, 2019.), te stvorilo dodatne poremećaje, uključujući veću fluktuaciju radne snage, gubitak produktivnosti te, očekivano, veću učestalost privremenog zapošljavanja, dok učinak na smanjenje nezaposlenosti nije potvrđen. Stoga neke novije studije (primjerice, Boeri, 2011. ili Centeno i Novo, 2012.) naglašavaju kako (visoka) zakonska zaštita zaposlenja kao takva više nije glavni problem na europskim tržištima rada, nego je to zapravo dualno tržište rada koje je posljedica parcijalnih reformi zakonske zaštite zaposlenja. ${ }^{1}$

Brojni su radovi tijekom posljednja dva desetljeća razvili teorijske modele koji pomažu u objašnjavanju ishoda parcijalnih reformi zakonske zaštite zaposlenja. Oni, među ostalim, uključuju radove Blanchard i Landier (2002.), Cahuc i Postel-Vinay (2002.), Boeri i Garibaldi (2007.), Sala, Silva i Toledo (2012.), Cahuc, Charlot i Malherbet (2016.) i Tejada (2017.), dok Bentolila, Dolado i Jimeno (2019.) u recentnom radu daju koristan pregled ne samo teorijskih nego i empirijskih nalaza. Tako, na primjer, Blanchard i Landier (2002.) - u slučaju liberalizacije privremenih ugovora bez ikakvih promjena troškova stalnog zapošljavanja - predviđaju dva glavna učinka: poduzeća će, kako bi dobila uvid u njihovu produktivnost, vjerojatno zaposliti nove radnike na određeno, ali je istovremeno manje vjerojatno da će ih zadržati za stalno. Oni testiraju model na francuskim podatcima za mlade radnike i pokazuju da su reforme povećale fluktuaciju bez značajnog smanjenja trajanja nezaposlenosti, dok je učinak na blagostanje negativan (Blanchard i Landier, 2002.). Nadalje, model uparivanja (engl. matching model) u radu Cahuc i Postel-Vinay (2002.) sugerira da što su veći troškovi otpuštanja, to je manji udio privremenih poslova koji će prerasti u stalna radna mjesta, čime se povećava nezaposlenost i smanjuje ukupno blagostanje.

Empirijski radovi o parcijalnim reformama radnog zakonodavstva razlikuju se prema makro ili mikro pristupu, ali i prema provođenju analiza na razini više država ili samo pojedine zemlje. Primjerice, Kahn (2007.; 2010.) tvrdi da je mikro pristup u ovom kontekstu prikladniji i daje važna empirijska otkrića u analizama na razini više država. U radu iz 2007., pokazuje kako stroža zakonska zaštita zaposlenja (za stalne ugovore) za sedam naprednih gospodarstava povećava relativne stope nezaposlenosti za mlade, imigrante i žene, a povećava i učestalost privremenog zapošljavanja slabo kvalificiranih, mladih i žena, posebice imigrantkinja (Kahn, 2007.). U radu iz 2010., na uzorku od devet europskih zemalja, otkriva da politike koje olakšavaju otvaranje privremenih radnih mjesta u prosjeku povećavaju vjerojatnost da će radnici češće raditi na

${ }^{1}$ Za više detalja o dualnim tržištima rada (u Europi) vidjeti Saint-Paul (1996.), Boeri (2011.) ili Bentolila, Dolado i Jimeno (2019.). 
privremenim poslovima potičući zamjenu stalnog rada privremenim. S druge strane, u njegovim radovima mogu se pronaći i dokazi da smanjenje (zakonskih) ograničenja (troškova) za ugovore na neodređeno može imati pozitivan utjecaj na povećanje zaposlenosti ili barem na smanjenje rizika od privremenog zaposlenja (Kahn, 2010.).

Iako imaju značajan doprinos u literaturi, analize situacija u više zemalja često ne mogu razlikovati određene čimbenike specifične za pojedinu zemlju ili uspostaviti valjanu kontrolnu skupinu (Fuest, Peichl i Siegloch, 2018.), pa su posljednjih godina sve učestaliji radovi usredotočeni na parcijalne reforme radnog zakonodavstva u pojedinačnim zemljama. To su, primjerice, radovi Centeno i Novo (2012.) za Portugal, Messe i Rouland (2014.) za Francusku, Vodopivec, Laporsek i Vodopivec (2016.) za Sloveniju, ili Hijzen, Mondauto i Scarpetta (2017.) za Italiju. U analizi portugalske reforme iz 2004., Centeno i Novo (2012.) pronalaze da se udio ugovora na određeno vrijeme, zajedno s većom fluktuacijom radne snage, povećao u poduzećima koja imaju između 11 i 20 zaposlenika, budući da je reforma povećala zaštitu (troškove) zapošljavanja na neodređeno upravo za takva poduzeća. S obzirom na različite razine zaštite radnika različitih dobnih skupina u Francuskoj, odnosno, budući da je zaštita stroža za otpuštanje radnika starijih od 50 godina, Messe i Rouland (2014.) analiziraju učinke reforme zaštite zaposlenja vezane uz dob iz 1999. - koja je povećala troškove samo za velika poduzeća - i otkrivaju značajan pozitivan učinak reforme na poticaje poduzećima za obučavanje starijih radnika. Vodopivec, Laporsek i Vodopivec (2016.) zaključuju da je reforma 2013. u Sloveniji - koja je povećala zaštitu ugovora na određeno vrijeme dok je smanjila zaštitu ugovora na neodređeno - smanjila segmentaciju tržišta rada i povećala vjerojatnost zapošljavanja na neodređeno. Slično kao i u studiji Messea i Roulanda (2014.) za Francusku, Hijzen, Mondauto i Scarpetta (2017.) analiziraju različite razine zaštite zaposlenja povezane s veličinom poduzeća na privremeno zapošljavanje u Italiji i pronalaze da stroža zaštita zaposlenja u većim poduzećima povećava fluktuaciju radnika, kao i učestalost privremenog zapošljavanja, te vodi ka smanjenju produktivnosti rada.

Segmentacija ili dualnost hrvatskog tržišta rada već se neko vrijeme spominje u literaturi; međutim, uglavnom na deskriptivnoj razini (npr. Račić, Babić i Podrug, 2005.; Franičević, 2011.; ili Brkić, 2015.). Ipak, postoje dva pokušaja empirijskog testiranja učinka (rigidnog) radnog zakonodavstva na tržište rada u Hrvatskoj. Tako Tomić i Domadenik (2012.) pokazuju da je u razdoblju 1996. 2006. došlo do nepovoljne selekcije na hrvatskom tržištu rada zbog visokih troškova otpuštanja; ali i da je razina obrazovanja značajnija za zapošljavanje te zaključuju da se utjecaj troškova otpuštanja na vjerojatnost zaposlenja smanjio nakon reforme iz 2003. Matković (2013.) istražuje koncept „fleksisigurnosti“ u kontekstu regulatornih promjena uvedenih početkom 2000-ih i sugerira da je rast zaposlenosti na određeno vrijeme usporio i pozicionirao Hrvatsku tek ispod prosjeka EU nakon reformi, dok dodatna empirijska analiza pokazuje da se učestalost privremenog zapošljavanja uglavnom odnosi na slabo kvalificirane i slabo plaćene poslove.

Slijedom navedenoga, ovaj rad pokušava popuniti jaz u literaturi o utjecaju zakonske zaštite zaposlenja na tržište rada u Hrvatskoj empirijskim testiranjem teorijskih podloga (parcijalne) reforme radnog zakonodavstva. 


\section{HRVATSKA: TRŽIŠTE RADA I INSTITUCIONALNO OKRUŽENJE}

Nakon turbulentnih 1990-ih, hrvatsko tržište rada konačno se stabiliziralo u prvoj polovici 2000ih. Međutim, globalna financijska i ekonomska kriza otkrila je sve slabosti hrvatskog gospodarstva. Iako je u Hrvatskoj započela tek 2009. godine, recesija je trajala punih šest godina s ogromnim posljedicama na tržište rada (Slika 1.). Razina zaposlenosti snažno je pala, uz određene dokaze (Svjetska banka, 2010.; Franičević, 2011.) koji sugeriraju da se u ranoj fazi recesije to uglavnom radilo putem privremenog zapošljavanja. ${ }^{2}$ Vukšić (2014.) nadalje naglašava da se tržište rada u krizi prilagođavalo smanjivanjem zaposlenosti u privatnom sektoru, ${ }^{3}$ prije svega u sektorima u kojima dominiraju muškarci, sa smanjenim udjelom zaposlenosti mladih, ali sve većim značenjem privremene i povremene (honorarne) zaposlenosti nakon 2011.

\section{Slika 1.}

Zaposlenost i privremena zaposlenost za stanovništvo u dobi 15-64 - Hrvatska i EU

Zaposlenost (\% stanovništva)

Izvor: Eurostat.

Iako se gospodarstvo počelo oporavljati krajem 2014., razina zaposlenosti još je uvijek znatno niža od one u 2007./2008.4 S druge strane, udio privremenog zapošljavanja među zaposlenicima (engl. employees $)^{5}$ porastao je na nove rekordne razine od preko $20 \%$ u 2017 . u usporedbi s oko $12-14 \%$ u razdoblju prije i u (ranom) kriznom razdoblju, dok je udio prekarnog rada („ugovori do tri mjeseca") najviši među zemljama EU još od 2013. (7,1\% svih zaposlenika u 2017.). Zanimljivo je da su - iako literatura predviđa porast privremenih ugovora tijekom recesije (Kahn, 2010.) - ugovori na određeno postali znatno učestaliji s početkom oporavka u Hrvatskoj. Istovremeno, prosječni udio samozaposlenih, 19\% u pretkriznom i ranom kriznom razdoblju (2007.-2011.), iznosio je tek 11\% u 2017. godini (Slika 2.), što upućuje da su se obrasci zapošljavanja u Hrvatskoj donekle izmijenili nakon recesije (Slika 1.).

\footnotetext{
${ }^{2}$ Matković (2013.) pokazuje da su se u pretkriznom razdoblju privremeni ugovori (ugovori na određeno) češće koristili u perifernom dijelu privatnog sektora, za zapošljavanje mladih i niskokvalificiranih radnika u manualnim rutinskim i uslužnim zanimanjima.

${ }^{3}$ Kao što se često navodi, zbog rigidnosti plaća hrvatsko tržište rada u krizi se prilagođavalo smanjivanjem zaposlenosti. Nalazi iz literature sugeriraju da su učinci zakonske zaštite zaposlenja na privremena zapošljavanja zapravo izraženiji u zemljama koje pokazuju veću rigidnost plaća (Kahn, 2007.).

${ }^{4}$ Dio objašnjenja za ovo leži u smanjenju broja stanovnika u radnoj dobi i promjeni generacijskog sastava radne snage zbog starenja stanovništva. Ipak, stopa zaposlenosti premašila je razinu iz 2008. tek u 2018., no ta godina nije obuhvaćena empirijskom analizom u ovom radu.

${ }^{5}$ Što isključuje samozaposlene i obiteljske radnike.
} 
Istovremeno, tijekom većeg dijela tranzicije hrvatsko se radno zakonodavstvo smatralo suviše rigidnim i često se proglašavalo glavnim krivcem za loše stanje na tržištu rada (Rutkowski, 2003.; Tomić i Domadenik, 2012.). Iako je izmjenama i dopunama zakona iz 2003. radno zakonodavstvo donekle liberalizirano, indeks zakonske zaštite zaposlenja (engl. employment protection legislation index - EPL index) ostao je iznad prosjeka EU i OECD zemalja (Matković i Biondić, 2003.). Ni novi zakon o radu iz 2009. nije donio značajne promjene u odredbama o „fleksibilizaciji“, odnosno EPL indeks ostao je nepromijenjen (Tomić, 2013.; Potočnjak, 2014.).

Međutim, pridruživanje EU u srpnju 2013. potaklo je dvije nove promjene u relativno kratkom roku. U lipnju 2013. se izmjenama i dopunama postojećeg Zakona o radu uvodi liberalizacija zaštite zaposlenja za privremene ugovore (engl. employment protection for temporary contracts - EPT index) i zaštite zaposlenja kod kolektivnih otpuštanja (engl. employment protection for collective dismissals - EPC index). ${ }^{6}$ Glavna je svrha bila ne samo povećati fleksibilnost tržišta rada, nego i usklađivanje hrvatskih propisa s onima u EU (Kunovac, 2014.; Potočnjak, 2014.). Dio odredbi koje se odnose na ugovore na neodređeno (engl. employment protection for regular contracts - EPR index) je ostao nepromijenjen.7 Međutim, već sljedeće godine (u srpnju 2014.) ${ }^{8}$ donošenje novog Zakona o radu opravdano je potrebom za daljnjim usklađivanjem nacionalnog zakonodavstva s onime u EU (Potočnjak, 2014.). Tim je zakonom uvedena liberalizacija zaštite zaposlenja za ugovore na neodređeno (EPR indeks) ${ }^{9}$ i daljnja liberalizacija zaštite zaposlenja za kolektivna otpuštanja (EPC indeks). Indeks zaštite zaposlenja za privremene ugovore (EPT indeks) ovom prilikom ostao je nepromijenjen, unatoč određenim promjenama koje se tiču liberalizacije u području agencija za privremeno zapošljavanje. 10

Tablica 1. sažima izmjene radnog zakonodavstva koristeći pritom pokazatelje OECD-a za zaštitu zaposlenja za ugovore na neodređeno (EPR indeks), kolektivna otpuštanja (EPC indeks) i ugovore na određeno (EPT indeks). ${ }^{11}$ Iako su neke nove odredbe donijele promjene u vrijednostima indeksa, opći je dojam da je opseg provedenih reformi prilično ograničen, pa je i dalje prisutna potreba za daljnjom reformom na tržištu rada (HNB, 2014.; Potočnjak, 2014.).

\footnotetext{
${ }^{6}$ Zakon o izmjenama i dopunama Zakona o radu (NN 73/13.) donesen je 18. lipnja 2013. (stupio na snagu nakon 8 dana).

${ }^{7}$ Izmjenama zakona iz 2013. uvedena je mogućnost da prvi ugovor na određeno vrijeme traje duže od tri godine (sklapanje uzastopnih ugovora o radu ostaje ograničeno na najviše tri godine), dok su odredbe o kolektivnim viškovima radnika pojednostavljene i cijeli je postupak skraćen.

${ }^{8}$ Zakon o radu (NN 93/14.) donesen je 30. srpnja 2014. (stupio na snagu nakon 8 dana).

${ }^{9}$ Glavne promjene u tom pogledu bile su pojednostavljenje postupaka prilikom otpuštanja radnika na ugovorima na neodređeno (ukidanje odredbi o obaveznoj prekvalifikaciji ili premještaju na drugo radno mjesto prije otkaza), promjene u organizaciji rada s obzirom na radno vrijeme, uz potencijalno smanjenje troškova otpuštanja jer je naknada za raskid ugovora o radu sudskim putem smanjena s maksimalnih 18 na maksimalno 8 prosječnih plaća.

${ }^{10}$ Mogućnost rada preko agencije povećana je s jedne na tri godine. Međutim, u prosjeku je tijekom promatranog razdoblja manje od 1\% radnika zaposleno putem agencije za privremeno zapošljavanje, bez značajnijih promjena u posljednjih nekoliko godina. ${ }^{11}$ Više detalja o reformama zakonske zaštite zaposlenja u Hrvatskoj u 2013. i 2014. dostupno je u radovima Kunovc (2014.), HNB (2104.), Potočnjak (2014.) i Brkić (2015.), a dodatne informacije o ranijim reformama dostupne su u Matković i Biondić (2003.), Vukorepa (2010.), Tomić i Domadenik (2012.) i Tomić (2013.).
} 
Tablica 1.

Reforme zakonske zaštite zaposlenja u Hrvatskoj

\begin{tabular}{lccc}
\hline Indeksi zakonske zaštite zaposlenja & $\mathbf{2 0 0 8 .}$ & $\mathbf{2 0 1 3 .}$ & $\mathbf{2 0 1 4 .}$ \\
\hline - za ugovore na neodređeno vrijeme (EPR) & 2,55 & 2,55 & 2,28 \\
\hline - kod kolektivnih otpuštanja (EPC) & 3,75 & 3,00 & 2,25 \\
\hline - za ugovore na određeno vrijeme (EPT) & 2,21 & 1,96 & 1,96 \\
\hline $\begin{array}{l}\text { - za ugovore na neodređeno vrijeme, } \\
\text { uključujući kolektivna otpuštanja (EPRC) }\end{array}$ & 2,89 & 2,68 & 2,27 \\
\hline Omjer EPT-a i EPR- $a$ & 0,87 & 0,77 & 0,86 \\
\hline Omjer EPT-a i EPRC- $a$ & 0,76 & 0,73 & 0,86 \\
\hline
\end{tabular}

Napomena: Vrijednosti predstavljaju indekse zakonske zaštite zaposlenja (EPL indekse) temeljene na OECD-ovoj metodologiji. Izvor: Kunovac (2014.) i HNB (2014.).

Tako se liberalizacija radnog zakonodavstva, koju su neprestano zagovarali i poslovna zajednica i mnogi stručnjaci, odvila paralelno s i uz poticaj pristupanja EU, ali i na kraju šestogodišnje recesije i donošenjem nekih drugih (zakonodavnih) reformi koje su mogle utjecati na obrasce zapošljavanja. To su, primjerice, stručno osposobljavanje bez zasnivanja radnog odnosa za mlade ${ }^{12}$ ili sezonsko zapošljavanje s vaučerima u poljoprivredi. ${ }^{13}$ Nadalje, od 2015. poslodavac koji zaposli osobu mlađu od trideset godina na stalni ugovor (na neodređeno) može biti oslobođen plaćanja doprinosa do pet godina. ${ }^{14}$ U sljedećim će se poglavljima pokušati ustanoviti jesu li i kako promjene zakonodavstva o zaštiti zaposlenja utjecale na hrvatsko tržište rada.

\section{Metodologija I PODATCI}

\subsection{METODE}

Budući da je glavni cilj ovog rada istražiti učinak reforme(i) zakonske zaštite zaposlenja na učestalost pojave privremenog zapošljavanja te na ukupnu razinu zaposlenosti, idealan bi pristup bio upotreba nekih standardnih metoda evaluacije politika, kao što su, primjerice, razlike u razlikama (engl. differences-in-differences) ili neke od metoda uparivanja (engl. matching methods). Međutim, kako su reforme u ovom slučaju sveobuhvatne, odnosno, izmjene odredbi radnog zakonodavstva mogu imati učinak ne samo na zaposleno stanovništvo, već i na cjelokupno stanovništvo koje bi moglo dobiti zaposlenje; identifikacija uvjerljive tretirane skupine (engl. treatment group) nije izvjesna. Slično tome, ako bismo htjeli primijeniti neku drugu metodu procjene učinka (engl. impact evaluation method), poput dizajna regresije diskontinuiteta (engl. regresion discontinuity design RDD), bilo bi potrebno imati varijablu tretmana (engl. treatment or running variable), što je u ovom slučaju vrijeme; međutim, ponovo to nije jedinstveno za pojedinu osobu nego se odnosi na sve potencijalne sudionike na tržištu rada. Ipak, učinci reforme(i) zaštite zaposlenja na učestalost privremenog zapošljavanja mogu se promatrati kao slučaj namjere sudjelovanja (engl. intention-

\footnotetext{
12 Tomić i Žilić (2018.), primjerice, pokazuju da se broj sudionika u programu povećao s manje od pet stotina 2010. na više od 33 tisuće 2016.

${ }^{13}$ I stručno osposobljavanje bez zasnivanja radnog odnosa (do godinu dana) i sezonski rad u poljoprivredi putem vaučera (do 90 dana u godini) uvedeni su Zakonom o poticanju zapošljavanja (NN 57/12., 120/12., 16/17.).

14 Prema Zakonu o doprinosima (NN 84/08., 152/08., 94/09., 18/11., 22/12., 144/12., 148/13., 41/14., 143/14., 115/16., 106/18.). Prema podacima Hrvatskog zavoda za mirovinsko osiguranje broj ljudi koji koriste ovu mogućnost zapošljavanja povećao se s nešto više od 10 tisuća u ožujku 2015. na više od 83 tisuće na kraju 2017. (više od 108 tisuća na kraju 2018.).
} 
to-treat - ITT), jer reforma zapravo predstavlja ponudu tretmana (engl. treatment offer) čak i ako ne dovodi do privremenih ugovora u svim slučajevima.

Kako bi se izbjegli navedeni problemi, ovaj se rad oslanja na nešto drugačiji pristup u analizi učinaka reformi na ishode zaposlenosti u Hrvatskoj. U radu se preuzimaju metode korištene u radovima Kahna (2007.; 2010.) - koji primjenjuju različite modele vjerojatnosti u analizi učinaka reformi zaštite zaposlenja na zaposlenost u kontekstu više država - a koji se dodatno prilagođavaju na slučaj pojedinačne zemlje. U osnovi, procjenjuju se sljedeći modeli:

$$
\begin{gathered}
T E M P_{i t}=\alpha+\beta^{*} E P L_{-} \text {reform }+\delta^{\prime} X_{i t}+\omega_{t}+\varepsilon_{i t} \\
E M P_{i t}=\alpha+\beta^{*} E P L_{-} \text {reform }+\delta^{\prime} X_{i t}+\omega_{t}+\varepsilon_{i t}
\end{gathered}
$$

pri čemu je TEMP $P_{i t}$ dihotomna (engl. dummy) varijabla koja pokazuje da je osoba $i$ zaposlena na privremenom ugovoru (ugovoru na određeno) u mjesecu $t$, dok je $E M P_{i t}$ dihotomna (dummy) varijabla ako je osoba $i$ zaposlena (zaposlenik) u mjesecu $t$. EPL_reform označava reformsku varijablu (tretman), koja se dodaje osnovnom skupu kovarijata $\left(X_{i t}\right)$ kako bi se uzele u obzir reforme iz 2013. i 2014., dok $\omega_{t}$ predstavlja vremenski učinak.

U osnovi, odrednice zaposlenosti (kod poslodavca) i privremene zaposlenosti (jednadžbe 1 i 2) procjenjuju se pomoću probit regresija (procjenitelj najveće vjerojatnosti; (engl. maximum likelihood estimator), odnosno:

$$
\begin{aligned}
P_{r}\left(Y_{i t}\right. & =1)=P_{r}\left(\alpha+\beta^{*} E P L_{-} \text {reform }+\delta^{\prime} X_{i t}+\omega_{t}+\varepsilon_{i t} \geq 0\right) \\
& =\Phi\left(\alpha+\beta^{*} E P L_{-} \text {reform }+\delta^{\prime} X_{i t}+\omega_{t}\right)
\end{aligned}
$$

pri čemu je $Y_{i}$ ishod jednak 1 ako je osoba privremeno zaposlena, $X_{i}$ predstavlja skup individualnih, karakteristika kućanstva, geografskih i karakteristika posla ${ }^{15}, \Phi$ je funkcija standardne normalne kumulativne raspodjele koja prevodi diskretne vrijednosti $Y_{i}^{*}$ (pojedinčeva temeljna vjerojatnost bivanja u statusu zaposlenosti/privremene zaposlenosti, što je neopažena (latentna) varijabla) u vjerojatnost $\left(P_{r}\right)$ opaženog događaja $Y_{i}=1 \mathrm{uz}$ dane kovarijate, a $\beta$ je glavni parametar od interesa. ${ }^{16}$

Osim niza individualnih, karakteristika kućanstva i okruženja, u model se dodaju i reformske varijable (varijable tretmana) za privremene i stalne ugovore. Jedan od načina uključivanja reformi radnog zakonodavstva u model je uključivanje vrijednosti OECD-ovih indeksa zakonske zaštite zaposlenja (Tablica 1.) u različitim vremenskim razdobljima (kao u Kahn, 2007.), dok je druga mogućnost jednostavno uključivanje dihotomnih (dummy) varijabli za razdoblje u kojem su odredbe reformi bile na snazi (kao u Kahn, 2010.). S obzirom na to da literatura sugerira da je ono što zapravo utječe na učestalost privremenog zaposlenja rigidnost zaštite stalnog zaposlenja u odnosu na zaštitu privremenog zaposlenja, a ne sama zakonska zaštita privremenog (ili stalnog) zaposlenja (Blanchard i Landier, 2002.; Kahn, 2010.; Bentolila, Dolado i Jimeno, 2019.), u radu se

\footnotetext{
${ }^{15}$ Za više detalja vidjeti sljedeći odjeljak i Tablicu A1. u Dodatku.

$16 \mathrm{U}$ radu se testira i ne-slučajna selekcija pojedinaca u (privremeno) zaposlenje primjenom takozvane Heckmanove korekcije za selekciju, odnosno, model se procjenjuje u dvije faze gdje se u prvoj fazi procjenjuje vjerojatnost da se osoba zaposli (ili bude ekonomski aktivna), koja se zatim koristi kao parametar prilagodbe u jednadžbi u drugoj fazi.
} 
ocjenjuju i modeli koji sadržavaju i privremene i stalne reformske varijable u istoj specifikaciji. Međutim, procjenjuju se i modeli koji uključuju samo jednu od reformskih varijabli, imajući u vidu da se druga reforma (EPR iz srpnja 2014.) dogodila nakon što je prva reforma (EPT iz lipnja 2013.) već bila na snazi. Moguća endogenost reformi uzeta je u obzir dodavanjem vremenskog trenda, regionalnih dihotomnih (dummy) varijabli i kvartalnih stopa rasta BDP-a u model. Ovo bi trebalo dodatno kontrolirati i za stanje u gospodarstvu. ${ }^{17}$

Kako bi se ustanovilo da nije bilo učinka prije same reforme, odnosno da je prije reforme(i) postojala konstantna vjerojatnost privremenog zapošljavanja, u ovom radu se primjenjuje takozvana studija događaja (engl. event study). Iako se ova metoda češće koristi u financijskoj ekonometriji, odnosno, pri procjeni utjecaja nekog događaja na vrijednost poduzeća, odnedavno se koristi i u primijenjenoj mikroekonomiji koja analizira različite aspekte reformi (politike) na ishode na tržištu rada i blagostanje (primjerice, Simon, 2016.; Fuest, Peichl i Siegloch, 2018.; Perez-Truglia, 2019.), ali ne i, koliko je poznato, pri procjeni učinaka reforme radnog zakonodavstva na ishode na tržištu rada. U principu, u ovom slučaju dihotomne vremenske varijable određenog događaja zamjenjuju varijablu tretmana (reformsku varijablu) u regresijskom modelu. To bi značilo da se procjenjuje jednadžba (1.1) ili (1.2) gdje umjesto reformske varijable (EPL_reform) imamo skup dihotomnih (dummy) varijabli koje pokazuju broj razdoblja udaljenih (prije i poslije) reforme radnog zakonodavstva (događaj), odnosno:

$$
\begin{aligned}
& T E M P_{i t}=\alpha+\beta \sum_{j=-J}^{J} D_{j}+\delta^{\prime} X_{i t}+\omega_{t}+\varepsilon_{i t} \\
& E M P_{i t}=\alpha+\beta \sum_{j=-J}^{J} D_{j}+\delta^{\prime} X_{i t}+\omega_{t}+\varepsilon_{i t}
\end{aligned}
$$

gdje je $\sum_{j=-j}^{J} D_{j}$ vektor dihotomnih pokazatelja, od kojih je svaki jednak jedan kad je opservacija udaljena j razdoblja od nekog diskretnog događaja (Simon, 2016.), odnosno, od reforme radnog zakonodavstva (lipanj 2013. ili srpanj 2014.) u našem slučaju. Ako se učestalost privremenog zapošljavanja naglo promijeni u vrijeme događaja (reforma radnog zakonodavstva), procijenjeni $\beta$ parametri za razdoblja prije događaja trebaju biti jednaki (oko) nula, dok bi procijenjeni $\beta$ parametri za razdoblja nakon događaja trebali biti veći od nule. U skladu s time, moglo bi se očekivati da su ti parametri jednaki (oko) nuli za sva j-razdoblja (prije i poslije) od reforme u slučaju neke druge varijable ishoda na koju reforma radnog zakonodavstva ne utječe. U ovom slučaju se koristi vrijeme (mjesec i godina) ugovora za svaku osobu u uzorku kako bi se povezao događaj (reforma radnog zakonodavstva) s ishodom na tržištu rada određene osobe i pratilo ga se 24 mjeseca ( 8 tromjesečja) prije reforme i 24 mjeseca ( 8 tromjesečja) nakon reforme.18

\footnotetext{
${ }^{17}$ Linearni trend također bi trebao uračunati i eventualne razlike u trendovima prije reforme u učestalosti privremenog zapošljavanja, odnosno, trebao bi pomoći u apsorpciji lažno značajnog (engl. spuriously significant) koeficijenta (Simon, 2016.). ${ }^{18}$ Ovdje bi se moglo prigovoriti da je datum ugovora endogen jer je osoba zaposlena na temelju svojih opazivih i neopazivih karakteristika; međutim, u modelu se kontrolira i za ostale (opazive) karakteristike.
} 


\subsection{PODATCI}

Ključne informacije u ovom radu preuzete su iz mikropodataka Ankete o radnoj snazi (ARS) u razdoblju između 2007. i 2017. Premda postavljeni kao „rotirajući panel“, raspoloživi podatci u osnovi sadrže ponavljajuće presječne podatke (engl. cross-section), jer nije moguće pratiti pojedinaca tijekom vremena; međutim, ista se pitanja postavljaju različitom uzorku pojedinaca svaki put što znači da se uzorci tijekom vremena mogu uspoređivati. Osim detaljnih podataka o statusu pojedinaca na tržištu rada, ARS daje i bogat skup informacija o različitim socio-demografskim karakteristikama pojedinaca i njihovih kućanstava, kao i podatke o karakteristikama samog posla i njihovog poslodavca. Premda su podatci utemeljeni na godišnjoj razini, unutar ankete je dostupno točno vrijeme (godina, mjesec, tjedan) provođenja same ankete kao i točno vrijeme (godina, mjesec) početka trenutnog ugovora, što omogućuje utvrđivanje učestalosti (privremenog) zapošljavanja prije i nakon reforme. Dakle, u radu se primjenjujući odgovarajuće pondere - koriste mjesečni podatci dobiveni iz godišnjih anketa.

Zavisne varijable slijede standardne definicije Međunarodne organizacije rada (ILO) i Eurostata o statusu na tržištu rada (Slika 1.). To znači da je fokus na zaposlenicima kao „osobama koje rade za poslodavca u državnome ili privatnom sektoru i za svoj rad primaju naknadu u novcu ili naturi“, te na podskupini zaposlenika „čiji će glavni posao prestati nakon unaprijed određenog razdoblja ili nakon razdoblja koje nije unaprijed poznato, ali je definirano objektivnim kriterijima, poput dovršetka posla ili razdoblja odsutnosti zaposlenika koji je privremeno zamijenjen“. U glavnom dijelu analize izostavljamo samozaposlene osobe i obiteljske radnike, kao što je standardno u literaturi, jer na njihov radni status najvjerojatnije utječu potpuno različiti čimbenici od onih koji utječu na tipične zaposlenike.

Prethodna definicija privremenog zaposlenja može se činiti previše širokom jer uključuje, osim ugovora o radu na određeno vrijeme, različite oblike sezonskog i povremenog rada. Struka po tom pitanju nije jednoglasna. Na primjer, Tejada (2017.), na čileanskim podatcima, analizira širu definiciju privremenog zaposlenja koja, osim ugovora o radu na određeno vrijeme, uključuje i druge vrste nepredviđenih poslova (engl. contingent jobs), kao što su poslovi po zadatku (engl. per task), po usluzi (engl. per service) i sezonski poslovi, što je po njemu značajno u Čileu i drugim zemljama Latinske Amerike zbog izražene sezonalnosti. Kahn (2007.; 2010.) raspravlja o različitim definicijama privremenog zaposlenja ovisno o podatcima koje koristi - Međunarodno istraživanje pismenosti odraslih (engl. International Adult Literacy Survey - IALS) (Kahn, 2007.) i Panel kućanstava europske zajednice (engl. European Community Household Panel - ECHP) - i one koju koristi OECD. Općenito, definicija OECD-a bliža je gore navedenoj ${ }^{19}$, dok je Kahn (2007.; 2010.) proveo svoje analize usredotočujući se na užu definiciju koja pokriva samo ugovore na određeno vrijeme. On, međutim, pokazuje da su rezultati kvalitativno slični kada se koristi i šira definicija privremenog zaposlenja. Slijedom toga, sljedeći definiciju ILO-a i Eurostata, ali uzimajući u obzir (sezonski) karakter hrvatskog tržišta rada ${ }^{20}$ i utjecaj globalizacije i tehnologije (digitalizacija, platformna ekonomija), analiza je usmjerena na širu definiciju privremene zaposlenosti.

\footnotetext{
${ }^{19}$ Osim ugovora o radu na određeno vrijeme, definicija OECD-a za privremeno zapošljavanje obuhvaća radnike zaposlene preko agencije za privremeno zapošljavanje, dnevne radnike, pripravnike, osobe u shemama za otvaranje novih radnih mjesta, radnike koji imaju ugovor za specifičan posao (zadatak), one koji rade kao zamjene i dežurne (engl. on-call) radnike (OECD, 2002.).

20 Prethodno je spomenuto da je Vlada 2012. godine donijela zakon koji je omogućio sezonski rad u poljoprivredi s vaučerom do 90 dana godišnje. Međutim, udio sezonskih radnika među privremenim zaposlenicima se zapravo smanjio
} 
Ovdje je bitno upozoriti na još jednu stvar u vezi s privremenim zaposlenjem na temelju (hrvatskih) podataka ARS-a. Naime, 2014. je donekle promijenjena definicija privremenog zaposlenja tako što je dio radnika - s ugovorima o djelu, autorskim ili studentskim ugovorima - prebačen iz samozaposlenosti u privremeno (povremeno) zaposlenje (Slika 2.). Unatoč tome, između 2013. i 2014. udio radnika na povremenim poslovima povećao se s 0,5\% na 1,4\% ukupnog broja zaposlenika, nakon trenda pada tijekom krize (s prosječnim udjelom od 1,1\% u razdoblju 2007.17.). Očito je, međutim, da to ne može biti jedini razlog povećanja privremene zaposlenosti za 2,4 postotna boda u istom razdoblju (Slika 1.), jer povremeni ugovori čine manje od 4,5\% svih privremenih ugovora u razdoblju 2007.-17. (iako, 7,5\% nakon 2014.). Osim toga, drugi izvori podataka (HZZ i DZS) također ukazuju na porast privremene zaposlenosti nakon 2013. U radu će se ipak testirati i modeli temeljeni na užoj (samo ugovori na određeno vrijeme) i na široj definiciji zaposlenosti (ukupnoj zaposlenosti koja uključuje i samozaposlene).

\section{Slika 2.}

Struktura zaposlenih na hrvatskom tržištu rada (stanovništvo u dobi 15-64)
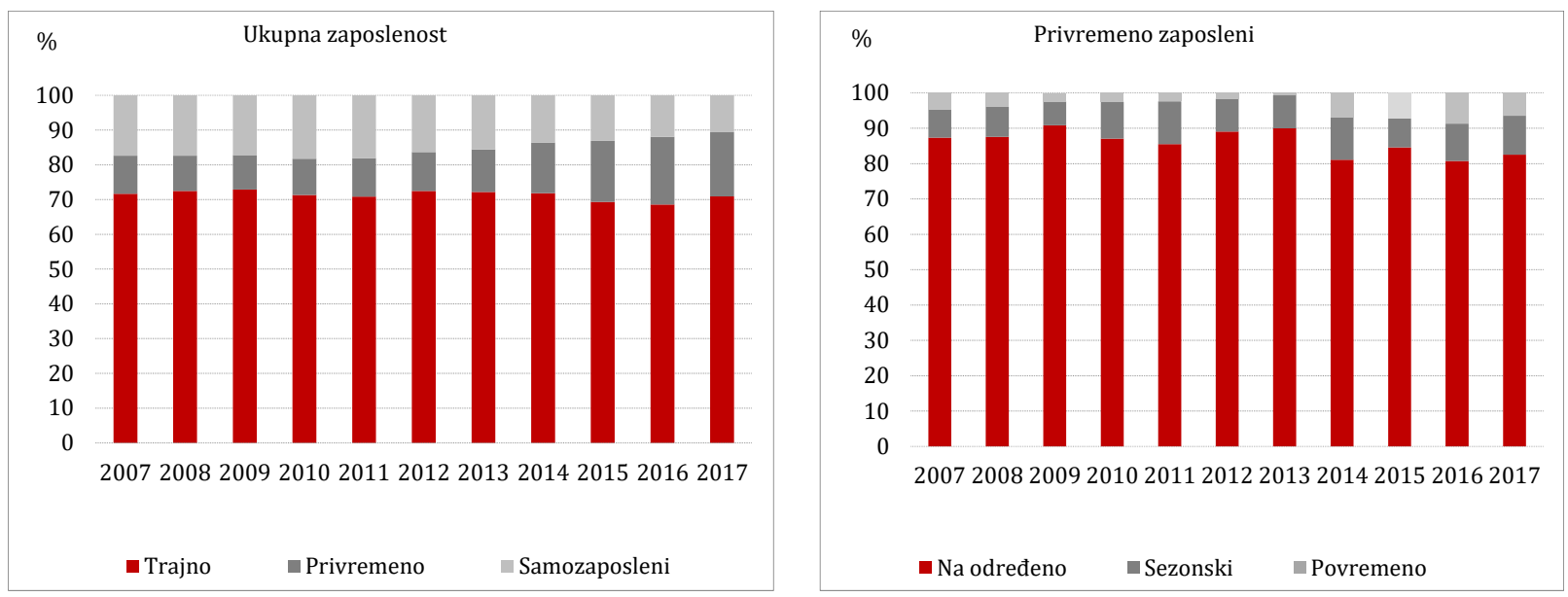

Izvor: ARS.

Pri procjeni učinaka reformi na zaposlenost, kao kovarijati $\left(X_{i t}\right)$ korištene su varijable iz bogatog skupa mikropodataka ARS-a, uključujući osnove individualne karakteristike kao što su dob (deset 5-godišnjih dobnih skupina), spol i nacionalnost (za rođene izvan Hrvatske), te bračni status i stupanj obrazovanja. Premda Kahn (2010.) navodi da su promjene u razini obrazovanja endogene u odnosu na status zaposlenosti i stoga ne uključuje razinu obrazovanja u procjenu vjerojatnosti zaposlenja, u literaturi se ipak smatra da je obrazovanje važna odrednica ne samo zaposlenosti nego i privremenog u odnosu na status stalnog zaposlenja te se stoga u ovom radu procjenjuje i model koji uključuje varijable obrazovanja. Dodatno su u modele uključene varijable regionalne pripadnosti i razine urbanizacije.

u 2012. i 2013. prije nego što je ponovno porastao u razdoblju 2014.-17. (isključujući 2015., Slika 2.), no uglavnom zbog sezonskog rada u turističkom sektoru. I neki drugi čimbenici, poput različitih oblika zaposlenja mladih uz vladine poticaje, mogli su utjecati na učestalost privremenog zapošljavanja; međutim, dva poticaja (stručno osposobljavanje bez zasnivanja radnog odnosa (privremeno zapošljavanje po definiciji) i zapošljavanje mladih na ugovor na neodređeno bez plaćanja doprinosa poslodavaca) zapravo djeluju u suprotnim smjerovima privremenog zapošljavanja. 
Premda bi varijable koje se tiču poduzeća, poput djelatnosti ili zanimanja mogle biti endogene, odnosno, pod utjecajem zakonodavstva o zaštiti zaposlenja (Kahn, 2007.; 2010.), u radu se procjenjuju i modeli koji uključuju karakteristike poduzeća kao što su veličina, javni/privatni sektor te djelatnosti (industrija) i zanimanje. Naime, kao što je navedeno drugdje u literaturi, uključivanje varijabli poput industrije i zanimanja može pomoći u kontroli drugih čimbenika koji utječu na učestalost privremenog zaposlenja, poput smanjenja troškova prilagodbe (Boeri i Garibaldi, 2007.). Osnovna deskriptivna statistika prikazana je u Tablici A1. u Dodatku. Iako bi bilo vrijedno uključiti i neke druge kovarijate u vektor $X$ (kao što su povijest zaposlenja ili pojedinačni fiksni učinci za kontrolu sposobnosti pojedinca), skup korištenih kontrolnih varijabli je u skladu s nalazima u literaturi.

\section{REZULTATI}

Slika 3. prikazuje mjesečne stope zaposlenosti (udio ukupnog broja zaposlenih te zaposlenika u ukupnom radno sposobnom stanovništvu od 15-64 godina) i privremene zaposlenosti (udio ukupnog broja privremenih te samo onih s ugovorima na određeno vrijeme u ukupnom broju zaposlenika od 15-64 godine) u razdoblju 2007.-17., s oznakama mjeseca reformi radnog zakonodavstva. Slika 3. predstavlja detaljniji prikaz pokazatelja već prikazanih na Slici 1. Premda samo deskriptivno, Slika 3. sugerira da postoji diskontinuitet (skok) u učestalosti privremenog zapošljavanja u vrijeme reforme, posebice kod reforme iz lipnja 2013. (liberalizacija privremenog zaposlenja). Skokovi ukupnog zaposlenja nisu tako očiti; naime, nakon 2013. zaposlenost raste, no bez očitog diskontinuiteta. Nadalje, čini se da je prije reformi trend učestalosti privremenih ugovora bio ravan (iako se - gledajući samo klasične ugovore na određeno vrijeme - počeo povećavati prije prve reforme), dok je trend stope zaposlenosti bio padajući (kao što se i očekuje u recesiji). Premda je teško iznijeti bilo kakve snažne zaključke bez daljnje analize, ovaj bi deskriptivni prikaz podrazumijevao da liberalizacija (privremene) zaštite zaposlenosti u Hrvatskoj nije dovela do očitog diskontinuiteta u ukupnom zapošljavanju; međutim, potaknula je porast broja ugovora o privremenom radu, što sugerira da je novo zakonodavstvo moglo omogućiti zamjenu trajnih ugovora o radu onima privremenog karaktera. 


\section{Slika 3.}

Mjesečni udjeli zaposlenih i privremeno zaposlenih za stanovništvo u dobi 15-64
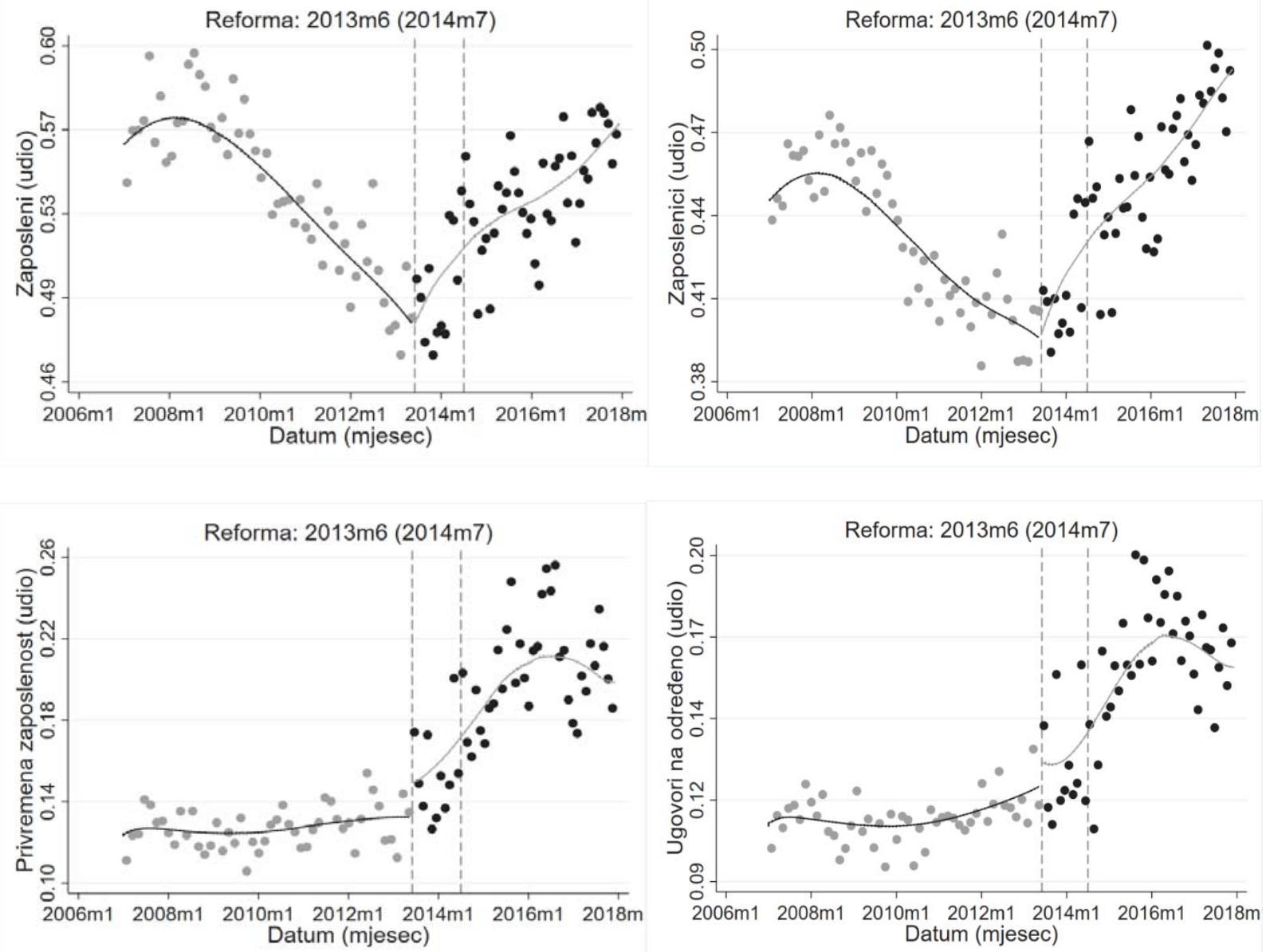

Napomene: Mjesečni podatci dobiveni su iz godišnjih skupova podataka. Ponderi nisu korišteni. Točkice predstavljaju udio zaposlenih/zaposlenika u ukupnom stanovništvu radne dobi (15-64) i/ili udio privremenih zaposlenika/ugovora na određeno vrijeme među svim zaposlenicima u dobi između 15 i 64 godine, dok linije predstavljaju lokalnu linearnu liniju zaglađivanja (engl. local linear smoothing plot).

Izvor: Izračun autorice na temelju ARS podataka.

\subsection{STUDIJA DOGAĐAJA}

Kako bismo dodatno ispitali deskriptivne nalaze, prikaz dobivenih rezultata započinjemo grafičkim prikazom studije događaja (jednadžbe 3.1 i 3.2) kako bismo testirali pretpostavku da prije reforme ne postoje različiti trendovi u privremenom i stalnom zapošljavanju, ali i da se pokaže kako postoji diskretan utjecaj reforme radnog zakonodavstva na češće privremeno zapošljavanje (Slika 4.). Kao što je već spomenuto, datum ugovora o radu koristi se kao varijabla vremena (za konstrukciju dihotomne (dummy) varijable za događaje) promatrajući osam tromjesečja prije i osam tromjesečja nakon reforme, pri čemu se zasebno ocjenjuju reforma zaštite zaposlenja za privremene ugovore (lipanj 2013. ili drugo tromjesečje 2013.) i za trajne ugovore (srpanj 2014. ili treće tromjesečje 2014.). Sljedeći rad Simona (2016.), koristi se linearni model vjerojatnosti, testirajući različite skupove kovarijata u modelu, zajedno s dihotomnim varijablama događaja i za privremeno zaposlenje i za status zaposlenika. 
Kao što je vidljivo u gornjem lijevom dijelu Slike 4., gotovo svi koeficijenti u razdoblju prije reforme su blizu nule i statistički neznačajni, dok su koeficijenti nakon reforme svi veći od nule i statistički značajni. Ovo bi sugeriralo da je reforma zaštite zaposlenja kojom su liberalizirani privremeni ugovori (drugi kvartal 2013.) značajno utjecala na vjerojatnost privremenog zapošljavanja. Liberalizacija zaštite trajnih ugovora o zapošljavanju (reforma iz trećeg kvartala 2014.), prikazana u gornjem desnom kutu, pokazuje nešto drugačije rezultate, odnosno vidljiv pozitivan (i značajan) post-reformski trend. No, premda blizu nule i koeficijenti prije reforme su statistički značajni. Slijedom toga, ne može se reći da je reforma iz srpnja 2014. imala značajan diskretni učinak na vjerojatnost privremenog zaposlenja, barem ne imajući u vidu rezultate studije događaja. ${ }^{21}$ To, međutim, nije neočekivano s obzirom na dobivene rezultate za reformu iz 2013. jer bi opaženi pozitivni učinak tog događaja nakon reforme trebao biti vidljiv i u razdoblju prije reforme iz 2014. (četiri preklapajuća tromjesečja), odnosno, reformu iz 2014. treba promatrati kao kumulativni učinak povrh prethodne reforme (2013.).

U donjem dijelu Slike 4. prikazani su rezultati za ukupnu zaposlenost: koeficijenti su blizu nule i uglavnom neznačajni, što upućuje da ni jedna reforma (ni 2013. niti 2014.) nije utjecala na ukupnu vjerojatnost novog zapošljavanja. To je pomalo iznenađujuće jer je stvarni cilj reforme bio povećati ukupnu zaposlenost; međutim, ovaj rezultat je u skladu s onim što je već pokazano u deskriptivnoj razini (Slika 3.).

Premda analiza prvenstveno služi kako bi se ustanovilo da nisu postojali različiti trendovi u razdoblju prije reforme te potencijalni diskretni učinci same reforme(i), vrijedi spomenuti nekoliko mogućih nedostataka ovakvog pristupa. Za početak, kada se analizira vjerojatnost bivanja zaposlenikom, odnosno, vjerojatnost bivanja u statusu zaposlenosti, alternativa su isključivo zaposlene osobe (samozaposleni i obiteljski radnici) s obzirom na to da samo oni imaju podatke o „početku ugovora“. Dakle, varijacije u modelu su u ovom slučaju ograničene. Drugi potencijalni nedostatak je moguća pristranost izostavljanja zaposlenih kojima su u međuvremenu istekli ugovori s obzirom na to da ovaj pristup identificira samo one ugovore koji traju dovoljno dugo da budu zabilježeni u nekim sljedećim istraživanjima ARS-a. Što je više vremena prošlo, veća je pristranost. Međutim, prilikom procjene istih modela (studije događaja) s ograničenjem duljine staža, dobivaju se vrlo slični rezultati: koeficijenti su nešto manji, no trendovi i statistička značajnost su isti. ${ }^{22} \mathrm{U}$ sljedećem poglavlju predstavljeni su detaljniji rezultati o odrednicama i privremene i ukupne zaposlenosti, uključujući reforme radnog zakonodavstva.

\footnotetext{
${ }^{21}$ Na Slici 4. su prikazani tromjesečni umjesto mjesečnih rezultata, jer „korištenje agregiranih dihotomnih (dummy) varijabli u studiji događaja smanjuje 'šum' i čini strukturu koeficijenta glatkijom" (Simon, 2016: 139). Isti rezultati procijenjeni na mjesečnoj razini dostupni su u Dodatku (Slika A1.) gdje je očito da budući da procjena sadrži „tri puta više koeficijenata s istim brojem opažanja, svaki je pojedinačni koeficijent manje precizno procijenjen (Perez-Truglia, 2019.: i).

${ }^{22}$ Dostupno na zahtjev.
} 


\section{Slika 4.}

Rezultati studije događaja - privremeno zapošljavanje (gore) i ukupna zaposlenost (dolje) za stanovništvo u dobi 15-64
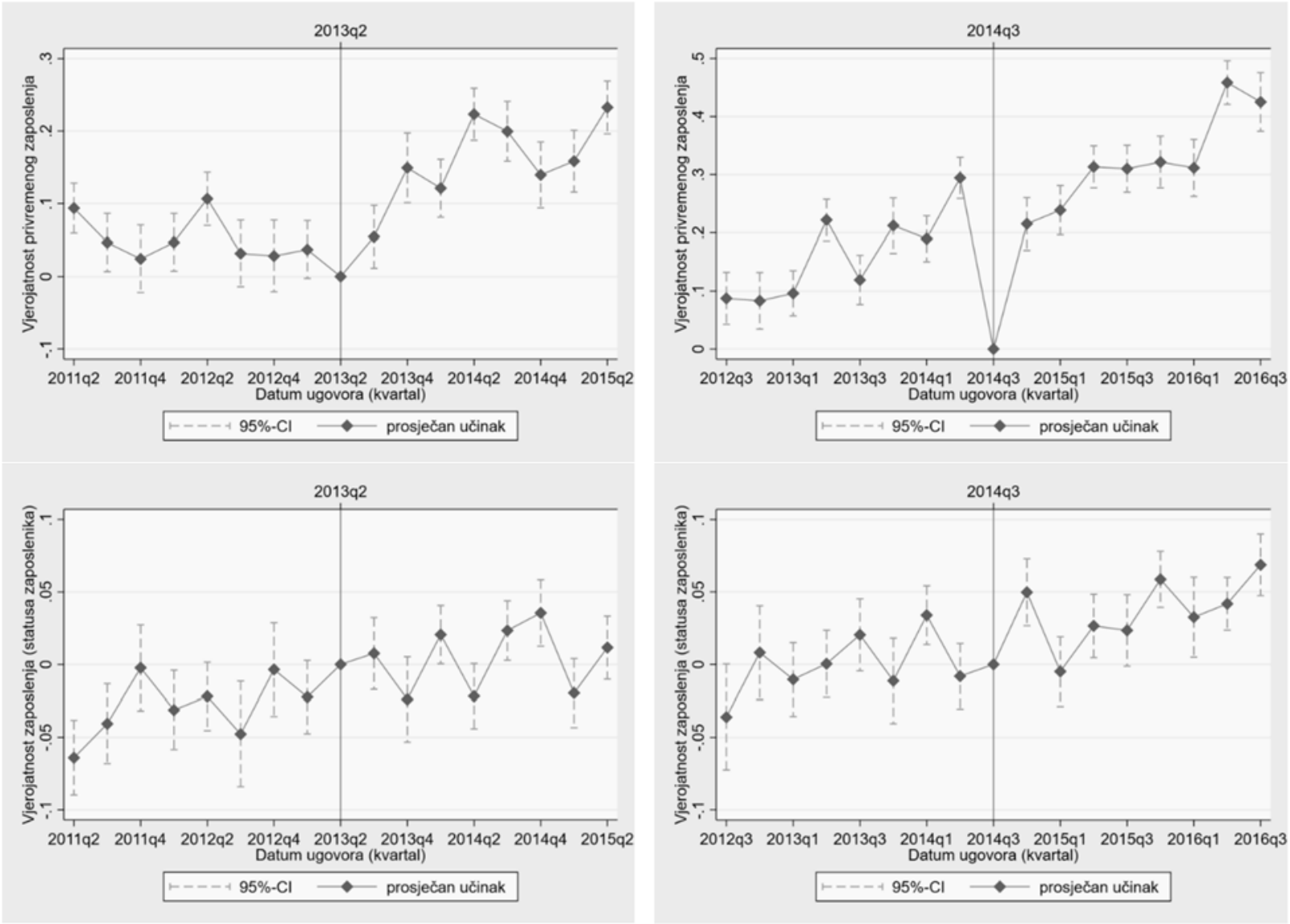

Napomene: Rezultati na temelju linearnog modela vjerojatnosti s robusnim standardnim greškama. Udio zaposlenih čine samo zaposlenici (15-64), ne i samozaposlene osobe i obiteljski radnici. Tromjesečni podatci dobiveni su iz godišnjih skupova podataka. U regresijama se kontrolira za osnovni skup individualnih karakteristika, odnosno, dob, spol, bračni status i nacionalnost, plus vremenski trend i kvartalni rast BDP-a. Druge specifikacije modela - poput onih koje uključuju obrazovanje, regiju i razinu urbanizacije - također su testirane i rezultati su manje-više isti (dostupno na zahtjev). Izvor: Izračun autorice na temelju ARS podataka.

\subsection{ODREDNICE PRIVREMENOG ZAPOŠLJAVANJA I UKUPNE ZAPOSLENOSTI}

U nastavku su prikazani rezultati probit regresija (jednadžba 2) za privremenu i za ukupnu zaposlenost (Tablica 2.). ${ }^{23}$ Naime, kao što je već spomenuto, grafička prezentacija studije događaja pomaže prvenstveno u utvrđivanju da nije bilo izraženih trendova u pred-reformskom razdoblju, dok bi regresije trebale pokazati prosječni učinak reformi na tržište rada. S obzirom na nelinearnost modela procjene u ovom radu, rezultati su prikazani u obliku graničnih učinaka, odnosno, kao prosječna promjena vjerojatnosti privremenog zaposlenja (ili ukupnog zaposlenja) kako se određeni kovarijat povećava za jednu jedinicu. U nastavku su prikazani rezultati procjena modela koji imaju obje reformske varijable u jednom modelu, ali i rezultati procjena modela koji ih imaju odvojeno, pritom imajući u vidu da „pojedinačne“ reformske varijable predstavljaju kumulativni učinak obje reforme. ${ }^{24}$

${ }^{23} \mathrm{U}$ Tablici 2. predstavljeni su rezultati preferirane specifikacije modela, dok su ostale specifikacije modela dostupne u Dodatku i/ili na zahtjev.

${ }^{24}$ Primjerice, druga reformska dummy varijabla (kolovoz 2014. - prosinac 2017.) uključuje i „kumulativni učinak” jer je ta reforma došla nakon što je prva reforma (iz lipnja 2013.) već bila provedena. Osim toga, ovdje su predstavljeni rezultati 
Osnovni rezultati sugeriraju da je reforma zaštite zaposlenja za privremene ugovore (iz lipnja 2013.) - u modelu zajedno s reformskom varijablom za liberalizaciju stalnih ugovora (kolovoz 2014. - prosinac 2017.) - imala pozitivan učinak na učestalost privremenog zapošljavanja dok je učinak na ukupnu zaposlenost negativan (iako statistički neznačajan). Ovaj je rezultat u skladu s interpretacijom ranije prikazane studije događaja (Slika 4.) u slučaju učinka reforme iz lipnja 2013. na ukupnu zaposlenost (nema učinka). Vrijedi napomenuti i da je učinak samo prve reforme (srpanj 2013. - srpanj 2014.) zapravo pozitivan i značajan u svim specifikacijama modela u pogledu vjerojatnosti privremenog zaposlenja, dok ostaje negativan ili statistički neznačajan u svim specifikacijama modela za ukupnu zaposlenost (ukupan broj zaposlenika). ${ }^{25} \mathrm{~S}$ obzirom na relativno kratko vremensko razdoblje (srpanj 2013. - srpanj 2014.) i opće ekonomske uvjete (recesija), ne čudi da učinak na vjerojatnost ukupnog zapošljavanja ostaje negativan u ovom razdoblju (nakon kontroliranja za druge varijable). Međutim, pozitivan učinak reforme na učestalost privremenog zapošljavanja sugerira pojavu dualnog tržišta rada.

Gledajući učinak reforme ugovora na neodređeno (kolovoz 2014. - prosinac 2017.), vidljiv je pozitivan učinak na vjerojatnost i privremenog i ukupnog zapošljavanja, bilo u specifikaciji modela sa samo tom reformskom varijablom bilo u kombinaciji s varijablom za reformu privremenih ugovora (Tablica 2.). Kao što je već spomenuto, na ovaj se učinak ne može gledati samo kao na reformu ugovora za stalno jer je ona nastupila samo godinu dana nakon liberalizacije privremenih ugovora. Zapravo, ova varijabla pokazuje utjecaj obje reforme na vjerojatnost, odnosno, privremenog zaposlenja, s tim da je veći učinak za ukupnu zaposlenost. Zanimljivo je da varijabla reforme trajnih ugovora jače utječe (koeficijent je veći) na vjerojatnost privremenog zapošljavanja u modelu koji uključuje i varijablu reforme privremenih ugovora, dodatno sugerirajući da ova varijabla vjerojatno preuzima i dio učinka reforme privremenih ugovora koja se dogodila godinu ranije. U slučaju ukupne zaposlenosti, učinak varijable reforme trajnih ugovora nešto je jači u modelu koji uključuje samo ovu varijablu (nakon srpnja 2014.).

Konačno, kombinirajući obje reforme u jednu dummy varijablu (srpanj 2013. - prosinac 2017.), vidi se njihov pozitivan učinak i na privremenu i na ukupnu zaposlenost, s tim što je u ovom slučaju učinak nešto jači za privremeno zapošljavanje (Tablica 2.). Pomalo iznenađujuće, čini se da je učinak reformske varijable za trajne ugovore (kolovoz 2014. - prosinac 2017.) jači od učinka varijable koja kombinira reforme i za privremene i trajne ugovore (srpanj 2013. - prosinac 2017.) u slučaju i privremene i ukupne zaposlenosti (Tablica 2.). Vrlo je vjerojatno da je liberalizacija stalnih ugovora potaknula porast ukupne zaposlenosti; međutim, naznaka da bi liberalizacija privremenog zaposlenja mogla imati negativan ili nikakav utjecaj na cjelokupno zapošljavanje zahtijeva dodatnu pozornost.

koji koriste dihotomne (dummy) varijable reformi; međutim, korištenje OECD-ovog EPL indeksa (Tablica 1.) umjesto dummy varijabli daje kvalitativno iste rezultate (dostupno na zahtjev). Uz to, svi modeli su procijenjeni koristeći i linearne regresije vjerojatnosti i dobiveni rezultati su približno isti kao i ovdje prikazani (dostupno na zahtjev).

${ }^{25}$ Dostupno u tablicama u Dodatku i/ili na zahtjev. 


\section{Tablica 2.}

Marginalni učinci nakon probit regresija - privremeno zapošljavanje među zaposlenicima i zapošljavanje (zaposlenici) za stanovništvo u dobi 15-64

\begin{tabular}{|c|c|c|c|c|c|c|}
\hline \multirow{2}{*}{$\begin{array}{l}\text { Marginalni učinci } \\
\text { liberalizacija }\end{array}$} & \multicolumn{3}{|c|}{$\begin{array}{l}\text { Privremeno zapošljavanje } \\
\text { (među zaposlenicima) }\end{array}$} & \multicolumn{3}{|c|}{$\begin{array}{c}\text { Ukupno zaposlenici } \\
\text { (unutar aktivnog stanovništva) }\end{array}$} \\
\hline & $\begin{array}{c}\text { Obje } \\
\text { reformske } \\
\text { varijable }\end{array}$ & $\begin{array}{c}\text { Kumulativni } \\
\text { učinak }\end{array}$ & $\begin{array}{l}\text { Samo EPR } \\
\text { reforma }\end{array}$ & $\begin{array}{c}\text { Obje } \\
\text { reformske } \\
\text { varijable } \\
\end{array}$ & $\begin{array}{c}\text { Kumulativni } \\
\text { učinak }\end{array}$ & $\begin{array}{c}\text { Samo EPR } \\
\text { reforma }\end{array}$ \\
\hline \multirow{2}{*}{ ЕРТ (7./2013.-7./2014.) } & $0,015^{* * *}$ & & & $-0,002$ & & \\
\hline & $(0,005)$ & & & $(0,006)$ & & \\
\hline \multirow{2}{*}{ EPR (8./2014.-12./2017.) } & $0,042 * * *$ & & $0,032 * * *$ & $0,068 * * *$ & & $0,069 * * *$ \\
\hline & $(0,005)$ & & $(0,004)$ & $(0,006)$ & & $(0,005)$ \\
\hline \multirow{2}{*}{$\begin{array}{l}\text { Obje reforme } \\
(7 . / 2013 .-12 . / 2017 .)\end{array}$} & & $0,025^{* * *}$ & & \multicolumn{3}{|c|}{$0,024^{* * *}$} \\
\hline & & $(0,005)$ & & & $(0,005)$ & \\
\hline
\end{tabular}

Napomene: Osim reformskih varijabli, ove specifikacije modela uključuju osnovni skup individualnih karakteristika, odnosno, dob, spol, bračni status, nacionalnost i stupanj obrazovanja, plus razinu urbanizacije i regije te vremenski trend i kvartalnu stopu rasta BDP-a. Udio zaposlenih čine samo zaposlenici (15-64), ne i samozaposlene osobe i obiteljski radnici. Detaljnije informacije o probit regresijama, uključujući ostale specifikacije modela, dostupne su u Dodatku i na zahtjev. Robusne standardne greške u zagradama. ${ }^{* *} p<0,01,{ }^{* *} p<0,05,{ }^{*} p<0,1$.

Izvor: Izračun autorice na temelju ARS podataka.

Nadalje, dobiveni rezultati sugeriraju da će žene, mladi, stranci, niskokvalificirani i samci iz ruralnih područja vjerojatnije završiti s privremenim ugovorima, što je u skladu s nalazima drugih autora (npr. Kahn, 2007. ili Matković, 2013.). Dodavanjem varijabli za regionalnu pripadnost, linearni vremenski trend i stope rasta BDP-a donekle se smanjuje učinak reformskih varijabli, dok dodavanje varijabli za poduzeća (veličina, vlasništvo, zanimanja i djelatnosti) dodatno smanjuje učinak reformskih varijabli na privremenu zaposlenost; međutim, glavni zaključci ostaju isti (Tablica A2. u Dodatku).

Premda neki teorijski modeli (Bentolila, Dolado i Jimeno, 2019.) predviđaju da bi strože odredbe zakonodavstva o privremenom zaposlenju u odnosu na stalne ugovore vodile manjoj učestalosti privremene zaposlenosti ${ }^{26}$, prethodno prikazani rezultati upućuju na suprotno. Međutim, postoje studije (npr. Booth, Dolado i Franck, 2002b; Kahn, 2007.; Cahuc, Charlot i Malherbet, 2016.) koje sugeriraju da zakonodavstvo o zaštiti zaposlenja za privremeno zapošljavanje zapravo ne utječe na učestalost privremenog zapošljavanja te da je zapravo regulacija stalnih ugovora važna i u ovom kontekstu. ${ }^{27}$ Dobiveni nalazi u ovom radu sugeriraju da nije samo ublažavanje odredbi za privremeno zapošljavanje važna odrednica privremene zaposlenosti u Hrvatskoj, nego je i reforma zaštite trajnog zaposlenja također utjecala na porast privremenih ugovora.

Valja podsjetiti i da su se reforme privremenih i trajnih ugovora u Hrvatskoj dogodile jedna za drugom (tijekom jedne godine), pa je možda trebalo više vremena kako bi učinak reforme privremenih ugovora (iz lipnja 2013.) postao vidljiv na tržištu rada, te je stoga rezultat te reforme vidljiv i u reformi ugovora za stalno (srpanj 2014.). Osim toga, možda je cjelokupna fleksibilizacija radnog zakonodavstva doprinijela raširenijem korištenju privremenih ugovora. Primjerice, Blanchard i

\footnotetext{
${ }^{26}$ Isti model predviđa da će u slučaju kada su ograničenja za stalne i privremene ugovore slična (ista), ublažavanje prvoga dovesti do više ugovora za stalno, ali i do više ugovora na određeno vrijeme. Po toj bi teoriji liberalizacija stalnih ugovora na kraju dovela do smanjenja udjela privremene zaposlenosti (Bentolila, Dolado i Jimeno, 2019.), što ne pokazuju rezultati u ovom radu.

27 Na primjer, Cahuc, Charlot i Malherbet (2016.) pokazuju da zaštita stalnih radnih mjesta nema značajan učinak na ukupnu zaposlenost; međutim, ipak potiče zamjenu stalnih privremenim radnim mjestima.
} 
Landier (2002.) predviđaju da će s liberalizacijom privremenih ugovora poduzeća vjerojatnije zaposliti nove radnike na privremenim ugovorima kako bi stekli uvid u njihovu produktivnost; međutim, također je manje vjerojatno da će ih zadržati na stalnim ugovorima. U Hrvatskoj postoji i mogućnost da poslodavci zbog dugotrajne recesije (i dalje) nerado zapošljavaju radnike na neodređeno i na taj način dolazi do povećanja privremene zaposlenosti usprkos liberalizaciji zaštite zaposlenja i ugovora na neodređeno. Ovaj se rad oslanja na indekse OECD-a o zakonskoj zaštiti zaposlenja kako bi se ustanovilo je li se reforma zaista dogodila; no, postoje i stavovi da se reforma dogodila samo „na papiru“, dok su u stvarnosti odredbe koje reguliraju ugovore na neodređeno ostale manje-više iste (HNB, 2014.; Potočnjak, 2014.).

U prethodnom je poglavlju također spomenuto kako postoji mogućnost da pojedinci nisu slučajno odabrani (selektirani) u zaposlenje (radnu aktivnost). Primjena Heckmanove korekcije za selekciju i korištenje udjela ovisnih osoba ( $<15$ i >64 godine) u kućanstvu kao 'instrumenta' u jednadžbi selekcije (prva faza) sugerira da je selekcija u (aktivnost) zaposlenje značajna, s negativnim rho koeficijentom (korelacija regresijske i jednadžbe selekcije) što govori da će ljudi koji imaju manju vjerojatnost za zapošljavanje (participaciju na tržištu rada) vjerojatnije imati privremeni ugovor. ${ }^{28}$ Međutim, kontrola za selekciju ne mijenja glavne nalaze prikazane ranije (Tablica 2.); koeficijenti reformskih varijabli su - nakon kontrole za selekciju - nešto viši kod privremenog zapošljavanja i nešto niži kod ukupne zaposlenosti, ali glavni zaključci ostaju isti.

Kako bi se dodatno ispitalo jesu li pojedinci možda sortirani (odabrani) u različite statuse na tržištu rada nakon reformi, modeli su za obje reforme (2013. i 2014.) zasebno procijenjeni za razdoblje prije i nakon reforme, naravno isključujući reformske varijable u ovom slučaju. ${ }^{29}$ Naime, možda pristupanje EU nije samo potaknulo promjenu radnog zakonodavstva; moglo je transformirati i hrvatsko tržište rada na druge načine. Slobodno kretanje radne snage jedna je od stvari koja je postala dominantni čimbenik za hrvatske radnike budući da su odljevi stanovništva u zemlje EU značajno porasli nakon srpnja 2013. To bi moglo utjecati na rezultate u ovom radu, jer je moglo promijeniti sastav domaćeg tržišta rada budući da oni koji su emigrirali i oni koji su ostali vjerojatno nemaju iste karakteristike. Međutim, dobiveni rezultati sugeriraju da nema značajnih razlika u koeficijentima dobivenim prije i poslije reforme: žene, mladi, stranci, niskokvalificirani i samci iz ruralnih područja vjerojatnije će završiti na privremenim ugovorima i prije i nakon reforme(i) (slično kao u Matković, 2013.), s iznimkom statističke značajnosti za varijablu urbanog mjesta stanovanja samo u razdoblju nakon reforme(i).

Ukratko, iako model studije događaja implicira da su reforme zakonodavstva o zaštiti zaposlenja iz 2013. i 2014. potaknule porast privremene, ali ne i ukupne zaposlenosti (Slika 4.), uz jači učinak reforme iz 2013., regresije vjerojatnosti, koje koriste reformske dihotomne (dummy) varijable za razdoblje prije i nakon reforme sugeriraju da su reforme utjecale i na ukupan broj zaposlenih. ${ }^{30}$ Naime, čini se da su reforme usmjerene na liberalizaciju odredbi za privremene i trajne ugovore

\footnotetext{
${ }^{28}$ Detaljni rezultati dostupni na zahtjev.

${ }^{29}$ Detaljni rezultati dostupni na zahtjev.

30 U modelima studije događaja korištene su specifične dihotomne (dummy) varijable koje se odnose na j razdoblja odmaka od reforme, ali koja su povezana s datumom ugovora o radu pojedinca, dok su u regresijama vjerojatnosti korištene reformske (dummy) varijable koje imaju vrijednost 1 nakon reforme i 0 prije reforme (nije posebno vezano za datum ugovora, odnosno, nije posebno vezano uz samog pojedinca).
} 
izazvale ne samo porast privremene zaposlenosti, već posljedično i porast ukupne zaposlenosti (Tablica 2.). Suprotno teorijskim predviđanjima, liberalizacija stalnih ugovora povećala je i učestalost privremenog zaposlenja. Objašnjenje je vjerojatno u činjenici da su zbog sveukupne liberalizacije radnog zakonodavstva - ali i zbog posljedica dugotrajne recesije - poslodavci bili spremniji ponuditi privremene ugovore, čak i nakon što su i trajni ugovori postali fleksibilniji. Kao što se očekivalo, liberalizacija ugovora na neodređeno povećala je ukupnu zaposlenost; međutim, čini se da liberalizacija privremenog zaposlenja nije uopće utjecala na ukupno zapošljavanje ili je čak utjecala negativno. S obzirom na to da je fleksibilnost trajnih ugovora dovela do povećanja ukupne zaposlenosti, samo parcijalna reforma, fokusirana isključivo na privremene ugovore, se može smatrati štetnom, jer povećava udio privremenih ugovora bez povećanja ukupne razine zaposlenosti.

\subsection{AlTERNATIVNE SPECIFIKACIJE}

Prethodno je spomenuto da su promjene u metodologiji ARS-a kao i dodatne zakonske izmjene mogle utjecati na pojačan udio privremene zaposlenosti od 2013. (Slike 1., 2. i 3.). Stoga se u ovom poglavlju dodatno testira nekoliko alternativnih specifikacija osnovnog modela (definicija zavisne varijable) kako bi se ustanovilo je li još nešto, osim reformi radnog zakonodavstva, utjecalo na glavne nalaze.

Za početak, na učestalost (privremenog) zapošljavanja mladih su mogli utjecati Zakon o poticanju zapošljavanja kojim se poticalo privremeno (na godinu dana) zapošljavanje mladih od 2012. te Zakon o doprinosima koji je poticao zapošljavanje mladih na ugovore na neodređeno od 2015. Iako ove dvije zakonske izmjene djeluju u suprotnom smjeru u pogledu učestalosti privremenog zaposlenja (mladih), kako bi se uzeli u obzir njihovi mogući učinci na osnovni set rezultata, sljedeći rad Tomić i Žilić (2018.), modeli iz Tablice 2. su procijenjeni ograničavajući uzorak na stanovništvo starije od 30 godina (Tablica 3.). 


\section{Tablica 3.}

Marginalni učinci nakon probit regresija - privremeno zapošljavanje među zaposlenicima i zapošljavanje (zaposlenici) za stanovništvo u dobi 30-64

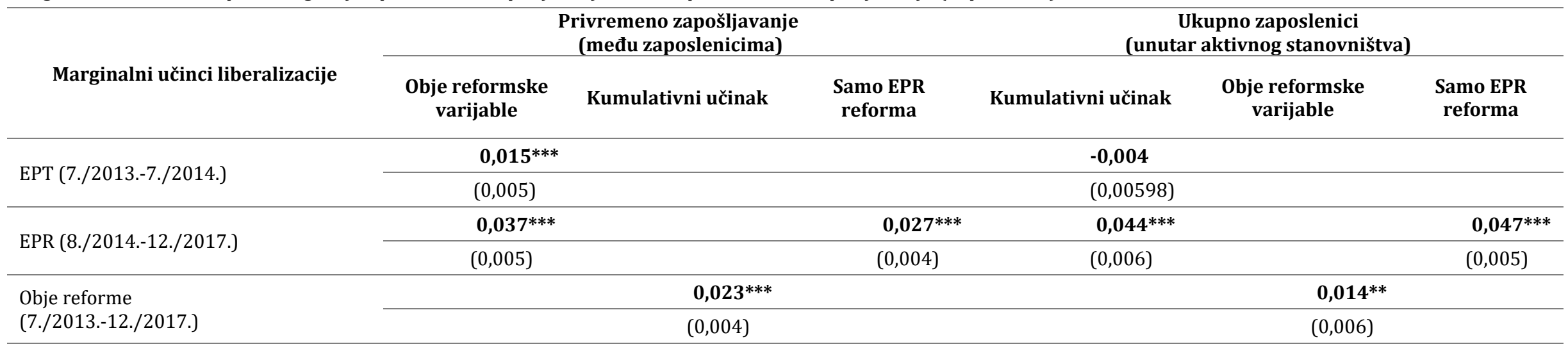

Napomene: Osim reformskih varijabli, ove specifikacije modela uključuju osnovni skup individualnih karakteristika, odnosno, dob, spol, bračni status, nacionalnost i stupanj obrazovanja, plus razinu urbanizacije i regiju te vremenski trend i kvartalnu stopu rasta BDP-a. Udio zaposlenih čine samo zaposlenici (30-64), ne i samozaposlene osobe i obiteljski radnici. Detaljnije informacije o probit regresijama dostupne su na zahtjev. Robusne standardne greške u zagradama. ${ }^{* * *} p<0,01,{ }^{* *} p<0,05,{ }^{*} p<0,1$

Izvor: Izračun autorice na temelju ARS podataka.

\section{Tablica 4.}

Marginalni učinci nakon probit regresija - ugovori na određeno, privremeno zapošljavanje među ukupno zaposlenima i ukupna zaposlenost za stanovništvo u dobi 15-64

\begin{tabular}{|c|c|c|c|c|c|c|c|c|c|}
\hline \multirow[b]{2}{*}{ Marginalni učinci liberalizacije } & \multicolumn{3}{|c|}{$\begin{array}{c}\text { Ugovori na određeno } \\
\text { (u odnosu na neodređeno) }\end{array}$} & \multicolumn{3}{|c|}{$\begin{array}{l}\text { Privremeno zapošljavanje } \\
\text { (među ukupno zaposlenima) }\end{array}$} & \multicolumn{3}{|c|}{$\begin{array}{c}\text { Ukupna zaposlenost } \\
\text { (unutar aktivnog stanovništva) }\end{array}$} \\
\hline & $\begin{array}{c}\text { Obje } \\
\text { reformske } \\
\text { varijable }\end{array}$ & $\begin{array}{l}\text { Kumulativni } \\
\text { učinak }\end{array}$ & $\begin{array}{l}\text { Samo EPR } \\
\text { reforma }\end{array}$ & $\begin{array}{c}\text { Obje } \\
\text { reformske } \\
\text { varijable }\end{array}$ & $\begin{array}{l}\text { Kumulativni } \\
\text { učinak }\end{array}$ & $\begin{array}{l}\text { Samo EPR } \\
\text { reforma }\end{array}$ & $\begin{array}{c}\text { Obje } \\
\text { reformske } \\
\text { varijable }\end{array}$ & $\begin{array}{l}\text { Kumulativni } \\
\text { učinak }\end{array}$ & $\begin{array}{c}\text { Samo EPR } \\
\text { reforma }\end{array}$ \\
\hline \multirow{2}{*}{ ЕРТ (7./2013.-7./2014.) } & $0,010 * *$ & & & $0,015^{* * *}$ & & & $-0,011 * * *$ & & \\
\hline & $(0,005)$ & & & $(0,004)$ & & & $(0,004)$ & & \\
\hline \multirow{2}{*}{ EPR (8./2014.-12./2017.) } & $0,029 * * *$ & & $0,023^{* * *}$ & $0,040^{* * *}$ & & $0,030^{* * *}$ & $0,044^{* * *}$ & & $0,051^{* * *}$ \\
\hline & $(0,005)$ & & $(0,004)$ & $(0,004)$ & & $(0,004)$ & $(0,004)$ & & $(0,003)$ \\
\hline \multirow{2}{*}{$\begin{array}{l}\text { Obje reforme } \\
(7 . / 2013 .-12 . / 2017 .)\end{array}$} & & $\mathbf{0 , 0 1 7} * * *$ & & & $0,024 * * *$ & & & $0,008 * *$ & \\
\hline & & $(0,004)$ & & & $(0,004)$ & & & $(0,004)$ & \\
\hline
\end{tabular}

Napomene: Osim reformskih varijabli, ove specifikacije modela uključuju osnovni skup individualnih karakteristika, odnosno, dob, spol, bračni status, nacionalnost i stupanj obrazovanja, plus razinu urbanizacije i regiju te vremenski trend $i$ kvartalnu stopu rasta BDP-a. Detaljnije informacije o probit regresijama dostupne su na zahtjev. Robusne standardne greške u zagradama. ${ }^{* * *} p<0,01,{ }^{* *} p<0,05,{ }^{*} p<0,1$.

Izvor: Izračun autorice na temelju ARS podataka. 
Tablica 3. pokazuje da procjena modela na populaciji od 30-64 godine ne mijenja glavne rezultate dostupne u Tablici 2. Procijenjeni koeficijenti su nešto manji, ali su predznaci i statistička značajnost ostali isti. Osim toga, rezultati studije događaja na ovom ograničenom uzorku (Slika 5.) otkrivaju obrazac sličan onome dostupnom i u osnovnoj procjeni (Slika 4.), s nešto većim oscilacijama između veličine koeficijenata, ali s istim općim zaključkom. Ovo sugerira da na glavne rezultate (Tablica 2.) ne utječe ni zapošljavanje mladih ni zakonske promjene u vezi s njihovim zapošljavanjem.

Nadalje, spomenuto je da bi definicija privremenog zaposlenja korištena u prethodnim modelima mogla biti previše široka u kontekstu reformi zakonske zaštite zaposlenja. Stoga je ovdje dodatno provedena analiza ograničena isključivo na ugovore na određeno vrijeme kao dio privremenog zaposlenja (bez sezonskih i povremenih ugovora). Grafički prikaz studije događaja s naglaskom na učestalost ugovora o radu na određeno vrijeme prikazan je na Slici 6., dok su glavni regresijski rezultati dostupni u Tablici 4 .

Slika 6. nalikuje gornjem dijelu Slike 4.; međutim, čak i u slučaju reforme iz lipnja 2013. (liberalizacija privremenih ugovora) neki su parametri u pred-reformskom razdoblju također statistički značajni (iako blizu nule). Rezultati u Tablici 4. vrlo su slični onima u Tablici 2. koji obuhvaćaju ukupno privremeno zaposlenje (ugovori na određeno vrijeme, sezonski i povremeni rad), s time da su procijenjeni koeficijenti nešto manji samo kod ugovora na određeno vrijeme. Rezultati sugeriraju da su provedene reforme utjecale na učestalost privremenog zapošljavanja. Pritom je učinak nešto izraženiji kada su obuhvaćeni svi oblici privremene zaposlenosti nego kada je fokus samo na ugovorima na određeno vrijeme.

Kako bi se dodatno testirali potencijalni problemi definiranja privremenog zaposlenja i promjene metodologije u 2014. (prebacivanje nekih povremenih ugovora između samozaposlenosti i privremenog zaposlenja), Tablica 4. predstavlja dvije dodatne procjene u kojima su zavisne varijable donekle drugačije definirane. Tako je ukupna privremena zaposlenost definirana kao udio u ukupnoj zaposlenosti (umjesto u ukupnom broju zaposlenika), dok se umjesto ukupnog broja zaposlenika uzima ukupna zaposlenost među aktivnim stanovništvom. Na taj se način uzimaju u obzir i kretanja među samozaposlenima unutar ukupne zaposlenosti. Uspoređujući Tablicu 4. s Tablicom 2., očito je da glavni nalazi ostaju isti (jedini relevantan izuzetak je statistička značajnost za reformsku varijablu liberalizacije privremenih ugovora u slučaju negativnog utjecaja na vjerojatnost ukupne zaposlenosti). Iako su koeficijenti nešto manji, može se zaključiti da je liberalizacija i privremenih i trajnih ugovora pozitivno utjecala na učestalost privremenog zapošljavanja, dok učinak liberalizacije privremenih ugovora na učestalost ukupnog zaposlenja nije vidljiv. Uzimajući u obzir sve navedeno, može se zaključiti kako definicija zavisnih varijabli (privremeno zapošljavanje i zaposlenost) nije presudna za glavne rezultate u ovom radu, s obzirom na to da alternativne specifikacije dovode do istih nalaza. 


\section{Slika 5.}

Rezultati studije događaja - privremeno zapošljavanje (gore) i ukupna zaposlenost (dolje) za stanovništvo u dobi 30-64
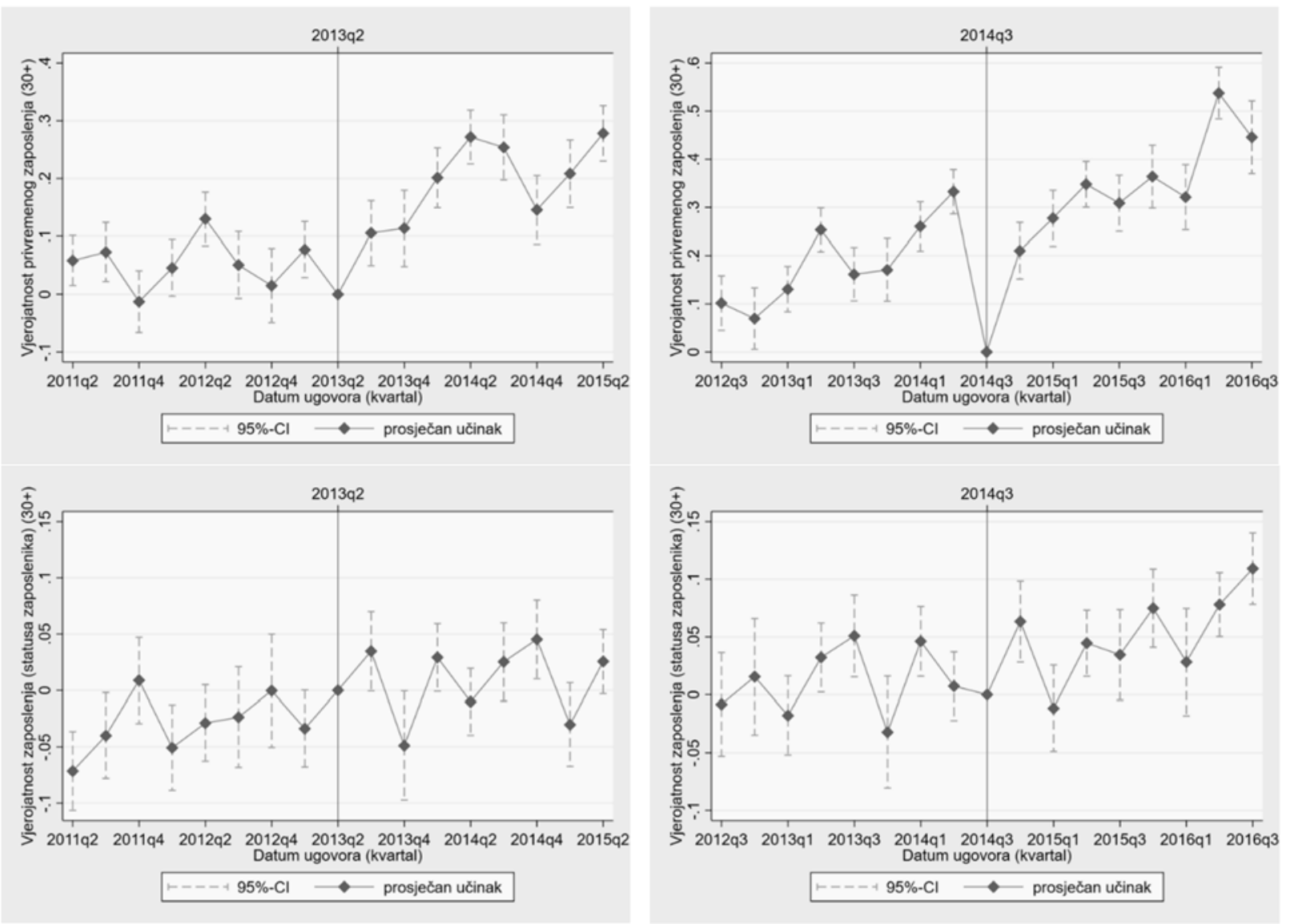

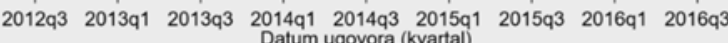
$-\cdots+\mathrm{Cr} \longrightarrow$ prosječan učinak

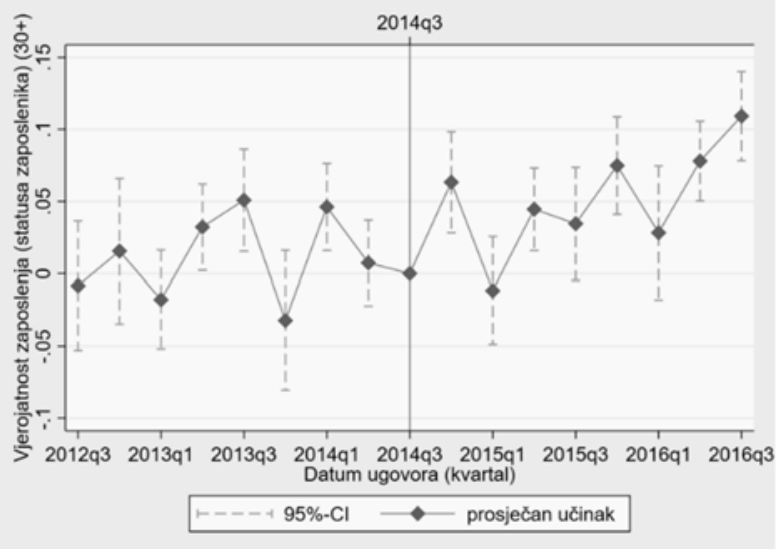

Napomene: Rezultati na temelju linearnog modela vjerojatnosti s robusnim standardnim greškama. Udio zaposlenih čine samo zaposlenici (30-64), ne i samozaposlene osobe i obiteljski radnici. Tromjesečni podatci dobiveni su iz godišnjih skupova podataka. U regresijama se kontrolira za osnovni skup individualnih karakteristika, odnosno, dob, spol, bračni status $i$ nacionalnost, plus vremenski trend i kvartalni rast BDP-a. Druge specifikacije modela - poput onih koje uključuju obrazovanje, regiju i razinu urbanizacije - također su testirane i rezultati su manje-više isti (dostupno na zahtjev). Izvor: Izračun autorice na temelju ARS podataka. 


\section{Slika 6.}

Rezultati studije događaja - samo ugovori na određeno za stanovništvo u dobi 15-64
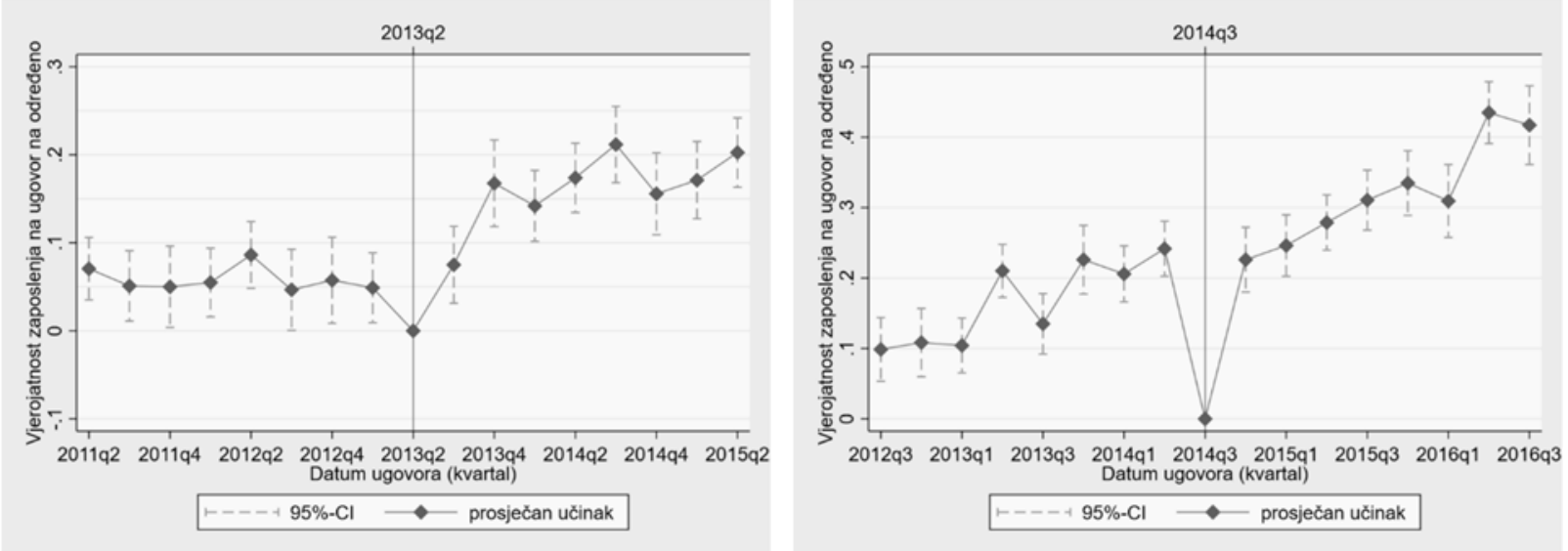

Napomene: Rezultati na temelju linearnog modela vjerojatnosti s robusnim standardnim greškama. Tromjesečni podatci dobiveni su iz godišnjih skupova podataka. U regresijama se kontrolira za osnovni skup individualnih karakteristika, odnosno, dob, spol, bračni status i nacionalnost, plus vremenski trend i kvartalni rast BDP-a. Druge specifikacije modela - poput onih koje uključuju obrazovanje, regiju i razinu urbanizacije - također su testirane i rezultati su manje-više isti (dostupno na zahtjev).

Izvor: Izračun autorice na temelju ARS podataka.

\section{ZAKLJUČCI}

Ovaj rad analizira učinke reformi radnog zakonodavstva iz 2013. i 2014. na zaposlenost, testirajući teorijska predviđanja dualnih reformi na tržištu rada iz literature na ishode na tržištu rada u Hrvatskoj. Zbog pridruživanja EU i potrebe usklađivanja zakonodavstva, liberalizirane su odredbe Zakona o radu i za privremene (2013.) i za trajne (2014.) ugovore, što omogućuje posebno zanimljivu evaluaciju javnih politika. Koristeći podatke ARS-a u razdoblju 2007.-17. i primjenjujući metodu studije događaja u kombinaciji s (probit) regresijama vjerojatnosti, glavni rezultati sugeriraju da su reforme zaštite zaposlenja iz 2013. i 2014. potaknule porast privremene zaposlenosti, dok su učinci na ukupnu zaposlenost jasno vidljivi samo kod druge reforme (stalni ugovori). Stoga se čini da je liberalizacija stalnih ugovora dovela do povećanja ukupne zaposlenosti, dok je parcijalna reforma, usredotočena na privremene ugovore, bila štetna jer je potaknula povećanje udjela privremenih ugovora bez povećanja ukupne razine zaposlenosti. Uz to, rezultati probit regresije sugeriraju da određene skupine stanovništva - žene, mladi, stranci, niskokvalificirani i samci iz ruralnih područja - imaju veću vjerojatnost završiti na poslovima s privremenim ugovorima. Ovi se rezultati dalje testiraju procjenom različitih specifikacija modela, uključujući i različite definicije privremenog zaposlenja, no dobiveni nalazi u velikoj mjeri potvrđuju osnovni skup rezultata.

Ipak, određena ograničenja ove analize svakako treba uzeti u obzir. Primjerice, u radu se koriste isključivo promjene OECD-ovih indeksa zakonske zaštite zaposlenja kako bi se definiralo je li se reforma zaista dogodila, no ti indeksi ne moraju u potpunosti odražavati praksu. To se posebno odnosi na fleksibilizaciju ugovora na neodređeno (reforma 2014.). Nadalje, pored samog Zakona o radu, zakonodavstvo o radnim odnosima uključuje i druge akte koji su mogli utjecati na neke promjene na hrvatskom tržištu rada posljednjih godina. Međutim, alternativne specifikacije modela koje su pokušale uzeti u obzir moguće učinke drugih zakonskih promjena nisu promijenile glavne nalaze. Konačno, recesija - uz popratne procese globalizacije i digitalizacije - i posljedična prilagodba i poslodavaca i radnika, mogli su promijeniti značaj privremenog u odnosu na stalno zaposlenje. 
Unatoč svemu navedenom ne treba zanemariti učinke reformi na učestalost privremene zaposlenosti ni na ukupne trendove na hrvatskom tržištu rada. To se ne odnosi samo na različite oblike zapošljavanja, nego može imati i šire učinke na formiranje ljudskog kapitala, povećanje nejednakosti i još veće poticanje emigracije. Nezavisna evaluacija javnih politika, i ex-ante i ex-post, u Hrvatskoj vidljivo izostaje, dok se u isto vrijeme zakonodavstvo stalno mijenja. Kako su reforme 2013. i 2014. uglavnom potaknute izvana, odnosno potrebom usklađivanja hrvatskih propisa s propisima EU-a, pouke iz Hrvatske mogle bi biti korisne za zemlje kandidatkinje i buduće pristupnice.

Daljnji koraci u analizi utjecaja radnog zakonodavstva na ishode na tržišta rada u Hrvatskoj trebali bi se usmjeriti i na druge ishode na tržištu rada, poput participacije na tržištu rada ili visine plaća, kao i na pojedinačne ishode na koje bi mogla utjecati povećana učestalost privremenog zaposlenja, uključujući formiranje braka, odluku o imaju djece, rješavanje stambenog pitanja i/ili život $s$ roditeljima. Budući da rezultati ovog rada ukazuju na veću vjerojatnost da će određene skupine zaposlenika, poput mladih ili žena, završiti s privremenim ugovorima o radu, više pažnje bi trebalo usmjeriti upravo na te specifične skupine. Moguće je da su dobiveni rezultati posljedica odluka na strani ponude, a ne na strani potražnje. Osim toga, premda bogata količinom pojedinačnih i varijabli povezanih s tržištem rada, ARS možda nije najbolji izvor podataka za analizu učinaka reformi radnog zakonodavstva na ishode na tržištu rada. Alternativa je upotreba administrativnih podataka s detaljnim specifikacijama različitih vrsta ugovora i njihovog trajanja ili/i upotreba podataka na razini poduzeća za ispitivanje jesu li odredbe zakona uzrokovale promjene u vrsti ugovora o radu između različitih sektora, veličina poduzeća i slično. U svakom slučaju, ovo je previše važno da bi se zanemarilo u akademskom diskursu. 


\section{REFERENCE}

1. Barbieri, P. i Cutuli, G., 2015. Employment protection legislation, labour market dualism, and inequality in Europe. European Sociological Review, 32(4), str. 501-516. https://doi.org/10.1093/esr/jcv058

2. Barbieri, P. i Cutuli, G., 2018. Dual labour market intermediaries in Italy: How to lay off „lemons“ - Thereby creating a problem of adverse selection. De Economist, 166(4), str. 477-502. https://doi.org/10.1007/s10645-018-9324-0

3. Bentolila, S., Dolado, J. K. i Jimeno, J. F., 2019. Dual Labour Markets Revisited. IZA Discussion Paper, Br. 12126. Bonn: Institute for the Study of Labor (IZA).

4. Blanchard, O. i Landier, A., 2002. The perverse effects of partial labour market reform: fixed-term contracts in France. The Economic Journal, 112(480), str. F214-F244. https://doi.org/10.1111/14680297.00047

5. Blossfeld, H. P. (i sur.), 2012. Selective flexibilization and deregulation of the labor market. The answer of Continental and Southern Europe. Stato e mercato, 32(3), str. 363-390.

6. Boeri, T. i Garibaldi, P., 2007. Two tier reforms of employment protection: A honeymoon effect?. The Economic Journal, 117(521), str. F357-F385. https://doi.org/10.1111/j.1468-0297.2007.02060.x

7. Boeri, T., 2011. Institutional Reforms and Dualism in European Labor Markets. U: O. C. Ashenfelter I D. Card, (ur.) Handbook of Labor Economics. Amsterdam: North-Holland, str. 11731236. https://doi.org/10.1016/s0169-7218(11)02411-7

8. Booth, A. L., Dolado, J. J. i Frank, J., 2002b. Symposium on temporary work: Introduction. The Economic Journal, 112(480), str. F181-F188. https://doi.org/10.1111/1468-0297.00044

9. Booth, A. L., Francesconi, M. i Frank, J., 2002a. Temporary jobs: stestring stones or dead ends?. The Economic Journal, 112(480), str. F189-F213. https://doi.org/10.1111/1468-0297.00043

10. Brkić, M., 2015. Labor market duality and the impact of prolonged recession on employment in Croatia. Croatian economic survey, 17(1), str. 5-45. https://doi.org/10.15179/ces.17.1.1

11. Cahuc, P. i Postel-Vinay, F., 2002. Temporary jobs, employment protection and labor market performance. Labour economics, 9(1), str. 63-91. https://doi.org/10.1016/s0927-5371(01)00051-3

12. Cahuc, P., Charlot, O. i Malherbet, F., 2016. Explaining the spread of temporary jobs and its impact on labor turnover. International Economic Review, 57(2), str. 533-572. https://doi.org/10.1111/iere.12167

13. Centeno, M. i Novo, Á. A., 2012. Excess worker turnover and fixed-term contracts: Causal evidence in a two-tier system. Labour Economics, 19(3), str. 320-328. https://doi.org/10.1016/j.labeco.2012.02.006

14. HNB, 2014. Bilten, Br. 209. Zagreb: Hrvatska narodna banka.

15. Eichhorst, W. i Marx, P., 2019. How Stable Is Labour Market Dualism? Reforms of Employment Protection in Nine European Countries. IZA Discussion Paper, Br. 12309. Bonn: Institute for the Study of Labor (IZA).

16. Franičević, V., 2011. Croatia: Prolonged crisis with an uncertain ending. U D. VaughanWhitehead, (ur.) Inequalities in the world of work: The effects of the crisis. Geneve: International Labour Organisation, str. 139-208. https://doi.org/10.4337/9780857937513.00011

17. Fuest, C., Peichl, A. i Siegloch, S., 2018. Do higher corporate taxes reduce wages? Micro evidence from Germany. American Economic Review, 108(2), str. 393-418. https://doi.org/10.1257/aer.20130570 
18. Hijzen, A., Mondauto, L. i Scarpetta, S., 2017. The impact of employment protection on temporary employment: Evidence from a regression discontinuity design. Labour Economics, 46, str. 64-76. https://doi.org/10.1016/j.labeco.2017.01.002

19. Kahn, L. M., 2007. The impact of employment protection mandates on demographic temporary employment patterns: International microeconomic evidence. The Economic Journal, 117(521), str. F333-F356. https://doi.org/10.1111/j.1468-0297.2007.02059.x

20. Kahn, L. M., 2010. Employment protection reforms, employment and the incidence of temporary jobs in Europe: 1996-2001. Labour Economics, 17(1), str. 1-15. https://doi.org/10.1016/j.labeco.2009.05.001

21. Kunovac, M., 2014. Employment protection legislation in Croatia. Financial theory and practice, 38(2), str. 139-172. https://doi.org/10.3326/fintp.38.2.2

22. Matković, T. i Biondić, I., 2003. Reforma Zakona o radu i promjena indeksa zakonske zaštite zaposlenja. Financijska teorija i praksa, 27(4), str. 515-528.

23. Matković, T., 2013. 'Flexicurity'through Normalization? Changes in Scope, Composition and Conditions of Temporary Employment in Croatia. U M. Koch and M. Fritz, (ur.) Non-Standard Employment in Europe. London: Palgrave Macmillan, str. 84-102. https://doi.org/10.1057/9781137267160_6

24. Nickell, S., 1997. Unemployment and Labor Market Rigidities: Europe versus North America. Journal of Economic Perspectives, 11(3), str. 55-74. https://doi.org/10.1257/jep.11.3.55

25. OECD, 2002. Employment Outlook. Paris: OECD.

26. Perez-Truglia, R., 2019. The effects of income transparency on well-being: Evidence from a natural experiment. NBER Working Paper, Br. w25622. National Bureau of Economic Research. https://doi.org/10.3386/w25622

27. Piton, C. i Rycx, F., 2018. The unemployment impact of product and labour market regulation: Evidence from European countries. IZA Discussion Papers, Br. 11582 https://doi.org/10.2478/izajolp-2019-0006

28. Potočnjak, Ž., 2014. Najznačajnije novine koje donosi novi Zakon o radu. Hrvatska pravna revija, 14(9), str. 14-30.

29. Račić, D., Babić, Z. ai Podrug, N., 2005. Segmentation of the labour market and employee rights in Croatia. Revija za socijalnu politiku, 12(1), str. 45-66. https://doi.org/10.3935/rsp.v12i1.20

30. Rutkowski, J., 2003. Analiza i prijedlozi poboljšanja tržišta rada u Hrvatskoj. Financijska teorija i praksa, 27(4), str. 495-513.

31. Saint-Paul, G., 1996. Dual labor markets: a macroeconomic perspective. Cambridge, MA i London: MIT press.

32. Sala, H., Silva, J. I. i Toledo, M., 2012. Flexibility at the margin and labor market volatility in OECD countries. The Scandinavian Journal of Economics, 114(3), str. 991-1017. https://doi.org/10.1111/j.1467-9442.2012.01715.x

33. Siebert, H., 1997. Labor Market Rigidities: At the Root of Unemployment in Europe. Journal of Economic Perspectives, 11(3), str. 37-54. https://doi.org/10.1257/jep.11.3.37

34. Simon, D., 2016. Does early life exposure to cigarette smoke permanently harm childhood welfare? Evidence from cigarette tax hikes. American Economic Journal: Astrlied Economics, 8(4), str. 128-159. https://doi.org/10.1257/astr.20150476

35. Tejada, M. M., 2017. Dual labor markets and labor protection in an estimated search and matching model. Labour Economics, 46, str. 26-46. https://doi.org/10.1016/j.labeco.2017.03.002 
36. Tomić, I. i Domadenik, P., 2012. Matching, adverse selection and labour market flows in a (post) transition setting: the case of Croatia. Post-communist economies, 24(1), str. 39-72. https://doi.org/10.1080/14631377.2012.647969

37. Tomić, I. i Žilić, I., 2018. Working for 200 euro? The effects of traineeship reform on labor market outcomes in Croatia. EIZ Working Papers, Br. 4. Ekonomski institut, Zagreb (EIZ).

38. Tomić, I., 2013. Essays on the labour market in a post-transition economy: the case of Croatia. Doktorska disertacija. Ljubljana: Faculty of Economics Ljubljana University.

39. Vodopivec, M., Laporsek, S. i Vodopivec, M., 2016. Levelling the playing field: the effects of Slovenia's 2013 labour market reform. IZA Discussion Paper, Br. 9783. Bonn: Institute for the Study of Labor (IZA).

40. Vukorepa, I., 2010. Novi zakon o radu. Revija za socijalnu politiku, 17(2), str. 333-337. https://doi.org/10.3935/rsp.v17i2.949

41. Vukšić, G., 2014. Employment and employment conditions in the current economic crisis in Croatia. Financial theory and practice, 38(2), str. 103-138. https://doi.org/10.3326/fintp.38.2.1

42. World Bank, 2010. Social Impact of the Crisis and Building Resilience. Zagreb: The World Bank. 


\section{DoDATAK}

Tablica A1.

Deskriptivna statistika

\begin{tabular}{|c|c|c|c|c|c|c|c|c|}
\hline \multirow{2}{*}{ Varijable } & \multicolumn{2}{|c|}{ Ukupno } & \multicolumn{2}{|c|}{$\begin{array}{l}\text { Ukupno } \\
\text { zaposleni }\end{array}$} & \multicolumn{2}{|c|}{ Zaposlenici } & \multicolumn{2}{|c|}{$\begin{array}{l}\text { Privremeno } \\
\text { zaposleni }\end{array}$} \\
\hline & Prosjek & $\begin{array}{l}\text { Std. } \\
\text { dev. }\end{array}$ & Prosjek & $\begin{array}{l}\text { Std. } \\
\text { dev. }\end{array}$ & Prosjek & $\begin{array}{l}\text { Std. } \\
\text { dev. }\end{array}$ & Prosjek & $\begin{array}{l}\text { Std. } \\
\text { dev }\end{array}$ \\
\hline \multicolumn{9}{|l|}{ Status na tržištu rada } \\
\hline Aktivni & 0,65 & 0,48 & & & & & & \\
\hline Zaposlenici & 0,47 & 0,50 & 0,83 & 0,38 & & & & \\
\hline Samozaposleni & 0,15 & 0,36 & 0,15 & 0,36 & & & & \\
\hline Privremeno zaposleni & 0,16 & 0,36 & 0,16 & 0,36 & 0,16 & 0,36 & & \\
\hline Ugovori na određeno & 0,13 & 0,34 & 0,13 & 0,34 & 0,13 & 0,34 & 0,85 & 0,35 \\
\hline Prekarni rad & 0,05 & 0,22 & 0,05 & 0,22 & 0,05 & 0,22 & 0,33 & 0,47 \\
\hline \multicolumn{9}{|l|}{ Dob } \\
\hline 15-19 (ref.) & 0,09 & 0,28 & 0,01 & 0,10 & 0,01 & 0,10 & 0,04 & 0,20 \\
\hline $20-24$ & 0,09 & 0,29 & 0,06 & 0,24 & 0,07 & 0,25 & 0,19 & 0,40 \\
\hline $25-29$ & 0,10 & 0,30 & 0,12 & 0,32 & 0,13 & 0,34 & 0,24 & 0,43 \\
\hline $30-34$ & 0,10 & 0,30 & 0,14 & 0,35 & 0,15 & 0,35 & 0,16 & 0,37 \\
\hline $35-39$ & 0,10 & 0,30 & 0,14 & 0,35 & 0,14 & 0,35 & 0,11 & 0,31 \\
\hline $40-44$ & 0,10 & 0,30 & 0,14 & 0,34 & 0,14 & 0,34 & 0,08 & 0,28 \\
\hline $45-49$ & 0,11 & 0,31 & 0,13 & 0,34 & 0,13 & 0,34 & 0,07 & 0,26 \\
\hline $50-54$ & 0,11 & 0,31 & 0,13 & 0,33 & 0,12 & 0,33 & 0,06 & 0,23 \\
\hline $55-59$ & 0,11 & 0,31 & 0,09 & 0,29 & 0,08 & 0,28 & 0,03 & 0,18 \\
\hline $60-64$ & 0,09 & 0,29 & 0,04 & 0,20 & 0,03 & 0,18 & 0,01 & 0,10 \\
\hline \multicolumn{9}{|l|}{$\begin{array}{l}\text { Osobne/karakteristike } \\
\text { kućanstva }\end{array}$} \\
\hline Žene & 0,50 & 0,50 & 0,45 & 0,50 & 0,47 & 0,50 & 0,48 & 0,50 \\
\hline U braku (kohabitaciji) & 0,59 & 0,49 & 0,68 & 0,47 & 0,66 & 0,47 & 0,43 & 0,50 \\
\hline Stranci & 0,11 & 0,31 & 0,10 & 0,30 & 0,10 & 0,30 & 0,10 & 0,31 \\
\hline $\begin{array}{l}\text { Udio ovisnih osoba } \\
\text { u kućanstvu }\end{array}$ & 0,14 & 0,18 & 0,15 & 0,18 & 0,15 & 0,18 & 0,13 & 0,17 \\
\hline \multicolumn{9}{|l|}{ Obrazovanje } \\
\hline $\begin{array}{l}\text { Osnovna škola i manje } \\
\text { (ref.) }\end{array}$ & 0,23 & 0,42 & 0,13 & 0,33 & 0,09 & 0,29 & 0,11 & 0,31 \\
\hline Srednja škola & 0,60 & 0,49 & 0,64 & 0,48 & 0,65 & 0,48 & 0,68 & 0,46 \\
\hline Više i visoko obrazovanje & 0,17 & 0,37 & 0,24 & 0,42 & 0,25 & 0,43 & 0,21 & 0,41 \\
\hline \multicolumn{9}{|l|}{ Geografske varijable } \\
\hline $\begin{array}{l}\text { Urbano mjesto } \\
\text { stanovanja }\end{array}$ & 0,61 & 0,49 & 0,62 & 0,49 & 0,65 & 0,48 & 0,60 & 0,49 \\
\hline $\begin{array}{l}\text { Središnja HR } \\
\text { (bez Zagreba) ref.) }\end{array}$ & 0,23 & 0,42 & 0,24 & 0,43 & 0,23 & 0,42 & 0,22 & 0,41 \\
\hline Istočna HR & 0,19 & 0,39 & 0,16 & 0,37 & 0,15 & 0,36 & 0,20 & 0,40 \\
\hline Zagrebačka regija & 0,25 & 0,43 & 0,27 & 0,45 & 0,29 & 0,45 & 0,22 & 0,42 \\
\hline Sjeverni Jadran & 0,13 & 0,33 & 0,14 & 0,35 & 0,14 & 0,35 & 0,13 & 0,34 \\
\hline Južni Jadran & 0,20 & 0,40 & 0,18 & 0,39 & 0,19 & 0,39 & 0,23 & 0,42 \\
\hline $\begin{array}{l}\text { Stopa nezaposlenosti } \\
\text { na razini županije }\end{array}$ & 0,19 & 0,08 & 0,18 & 0,08 & 0,18 & 0,08 & 0,19 & 0,08 \\
\hline \multicolumn{9}{|l|}{$\begin{array}{l}\text { Gospodarska situacija } \\
\text { (stopa rasta BDP-a) }\end{array}$} \\
\hline Kvartalno & 0,05 & 1,21 & 0,05 & 1,23 & 0,06 & 1,22 & 0,17 & 1,12 \\
\hline Godišnje & 0,34 & 3,46 & 0,36 & 3,51 & 0,41 & 3,48 & 0,82 & 3,27 \\
\hline \multicolumn{9}{|l|}{$\begin{array}{l}\text { Karakteristike } \\
\text { poslodavca }\end{array}$} \\
\hline Javni sektor & 0,36 & 0,48 & 0,36 & 0,48 & 0,36 & 0,48 & 0,21 & 0,41 \\
\hline
\end{tabular}




\begin{tabular}{|c|c|c|c|c|c|c|c|c|}
\hline \multirow{2}{*}{ Varijable } & \multicolumn{2}{|c|}{ Ukupno } & \multicolumn{2}{|c|}{$\begin{array}{l}\text { Ukupno } \\
\text { zaposleni }\end{array}$} & \multicolumn{2}{|c|}{ Zaposlenici } & \multicolumn{2}{|c|}{$\begin{array}{l}\text { Privremeno } \\
\text { zaposleni }\end{array}$} \\
\hline & Prosjek & $\begin{array}{l}\text { Std. } \\
\text { dev. }\end{array}$ & Prosjek & $\begin{array}{l}\text { Std. } \\
\text { dev. }\end{array}$ & Prosjek & $\begin{array}{l}\text { Std. } \\
\text { dev. }\end{array}$ & Prosjek & $\begin{array}{l}\text { Std. } \\
\text { dev. }\end{array}$ \\
\hline Malo poduzeće (ref.) & 0,57 & 0,50 & 0,57 & 0,50 & 0,56 & 0,50 & 0,68 & 0,47 \\
\hline Srednje poduzeće & 0,20 & 0,40 & 0,20 & 0,40 & 0,21 & 0,40 & 0,16 & 0,37 \\
\hline Veliko poduzeće & 0,23 & 0,42 & 0,23 & 0,42 & 0,23 & 0,42 & 0,16 & 0,37 \\
\hline \multicolumn{9}{|l|}{$\begin{array}{l}\text { Zanimanje } \\
\text { (Manageri - ref.) }\end{array}$} \\
\hline Stručnjaci & 0,14 & 0,35 & 0,14 & 0,35 & 0,16 & 0,36 & 0,12 & 0,32 \\
\hline Tehničari & 0,15 & 0,35 & 0,15 & 0,35 & 0,17 & 0,37 & 0,12 & 0,32 \\
\hline $\begin{array}{l}\text { Administrativni } \\
\text { službenici }\end{array}$ & 0,11 & 0,31 & 0,11 & 0,31 & 0,13 & 0,33 & 0,10 & 0,31 \\
\hline $\begin{array}{l}\text { Uslužna i trgovačka } \\
\text { zanimanja }\end{array}$ & 0,18 & 0,38 & 0,18 & 0,38 & 0,19 & 0,39 & 0,26 & 0,44 \\
\hline Poljoprivrednici & 0,08 & 0,27 & 0,08 & 0,27 & 0,01 & 0,08 & 0,01 & 0,09 \\
\hline Obrtnici & 0,13 & 0,33 & 0,13 & 0,33 & 0,13 & 0,34 & 0,13 & 0,33 \\
\hline $\begin{array}{l}\text { Rukovatelji } \\
\text { postrojenjima/strojevim } \\
\text { a }\end{array}$ & 0,10 & 0,31 & 0,10 & 0,31 & 0,12 & 0,32 & 0,11 & 0,32 \\
\hline Jednostavna zanimanja & 0,07 & 0,26 & 0,07 & 0,26 & 0,08 & 0,27 & 0,15 & 0,35 \\
\hline \multicolumn{9}{|l|}{$\begin{array}{l}\text { Djelatnost (Poljoprivreda, } \\
\text { šumarstvo i ribarstvo - ref.) }\end{array}$} \\
\hline $\begin{array}{l}\text { Industrija (osim } \\
\text { prerađivačke i } \\
\text { građevinarstva) }\end{array}$ & 0,03 & 0,17 & 0,03 & 0,17 & 0,04 & 0,19 & 0,02 & 0,13 \\
\hline Prerađivačka industrija & 0,18 & 0,38 & 0,18 & 0,38 & 0,20 & 0,40 & 0,18 & 0,39 \\
\hline Građevinarstvo & 0,08 & 0,27 & 0,08 & 0,27 & 0,08 & 0,27 & 0,09 & 0,28 \\
\hline $\begin{array}{l}\text { Trgovina, prijevoz, } \\
\text { smještaj i ugostiteljstvo + } \\
\text { komunikacije }\end{array}$ & 0,30 & 0,46 & 0,30 & 0,46 & 0,31 & 0,46 & 0,39 & 0,49 \\
\hline $\begin{array}{l}\text { Financijske, } \\
\text { osiguravateljske i } \\
\text { nekretninske aktivnosti }\end{array}$ & 0,03 & 0,18 & 0,03 & 0,18 & 0,04 & 0,19 & 0,02 & 0,15 \\
\hline $\begin{array}{l}\text { Javna uprava, obrana, } \\
\text { obrazovanje, zdravstvo i } \\
\text { socijalna skrb }\end{array}$ & 0,19 & 0,39 & 0,19 & 0,39 & 0,23 & 0,42 & 0,15 & 0,36 \\
\hline Ostale usluge & 0,09 & 0,29 & 0,09 & 0,29 & 0,09 & 0,28 & 0,11 & 0,31 \\
\hline Broj opažanja & \multicolumn{2}{|c|}{275.034} & \multicolumn{2}{|c|}{148.022} & \multicolumn{2}{|c|}{120.705} & \multicolumn{2}{|c|}{18.362} \\
\hline
\end{tabular}

Izvor: Izračun autorice na temelju ARS podataka 
Tablica A2.

Marginalni učinci nakon probit regresija za privremeno zapošljavanje

\begin{tabular}{|c|c|c|c|c|c|c|c|c|c|c|c|c|}
\hline \multirow{2}{*}{$\begin{array}{c}\text { Marginalni } \\
\text { učinci } \\
\text { liberalizacije }\end{array}$} & \multicolumn{4}{|c|}{ Obje reformske varijable } & \multicolumn{4}{|c|}{ Kumulativni učinak } & \multicolumn{4}{|c|}{ Samo EPR reforma } \\
\hline & (1) & (2) & (3) & (4) & (1) & (2) & (3) & (4) & (1) & (2) & (3) & (4) \\
\hline \multirow{2}{*}{$\begin{array}{l}\text { EPT (7./2013.- } \\
\text { 7./2014.) }\end{array}$} & $0,0402^{* * *}$ & $0,0149 * * *$ & $0,0154 * * *$ & $0,0118 * *$ & & & & & & & & \\
\hline & $(0,00399)$ & $(0,00501)$ & $(0,00500)$ & $(0,00481)$ & & & & & & & & \\
\hline \multirow{2}{*}{$\begin{array}{l}\text { EPR (8./2014.- } \\
\text { 12./2017.) }\end{array}$} & $0,0836 * * *$ & $0,0421 * * *$ & $0,0420^{* * *}$ & $0,0321 * * *$ & & & & & $0,0776^{* * *}$ & $0,0320^{* * *}$ & $0,0315 * * *$ & $0,0241 * * *$ \\
\hline & $(0,00242)$ & $(0,00547)$ & $(0,00546)$ & $(0,00525)$ & & & & & $(0,00235)$ & $(0,00430)$ & $(0,00430)$ & $(0,00415)$ \\
\hline \multirow{2}{*}{$\begin{array}{l}\text { Obje reforme } \\
(7 . / 2013 .- \\
12 . / 2017 .)\end{array}$} & & & & & $0,0742^{* * *}$ & $0,0246^{* * *}$ & $0,0249 * * *$ & $0,0192^{* * *}$ & & & & \\
\hline & & & & & $(0,00228)$ & $(0,00461)$ & $(0,00460)$ & $(0,00443)$ & & & & \\
\hline \multicolumn{13}{|l|}{ Dob: $15-19$ (ref.) } \\
\hline \multirow{2}{*}{$20-24$} & $-0,243^{* * *}$ & $-0,245^{* * *}$ & $-0,247^{* * *}$ & $-0,242^{* * *}$ & $-0,243^{* * *}$ & $-0,246^{* * *}$ & $-0,248^{* * *}$ & $-0,243^{* * *}$ & $-0,244^{* * *}$ & $-0,245^{* * *}$ & $-0,248^{* * *}$ & $-0,243^{* * *}$ \\
\hline & $(0,0166)$ & $(0,0165)$ & $(0,0167)$ & $(0,0178)$ & $(0,0166)$ & $(0,0166)$ & $(0,0168)$ & $(0,0178)$ & $(0,0165)$ & $(0,0165)$ & $(0,0167)$ & $(0,0178)$ \\
\hline \multirow{2}{*}{$25-29$} & $-0,380^{* * *}$ & $-0,383^{* * *}$ & $-0,381^{* * *}$ & $-0,359^{* * *}$ & $-0,380^{* * *}$ & $-0,384^{* * *}$ & $-0,382^{* * *}$ & $-0,361^{* * *}$ & $-0,379 * * *$ & $-0,383^{* * *}$ & $-0,381^{* * *}$ & $-0,360 * * *$ \\
\hline & $(0,0161)$ & $(0,0161)$ & $(0,0163)$ & $(0,0174)$ & $(0,0162)$ & $(0,0161)$ & $(0,0164)$ & $(0,0174)$ & $(0,0160)$ & $(0,0161)$ & $(0,0163)$ & $(0,0174)$ \\
\hline \multirow{2}{*}{$30-34$} & $-0,487^{* * *}$ & $-0,491^{* * *}$ & $-0,488^{* * *}$ & $-0,453^{* * *}$ & $-0,487^{* * *}$ & $-0,492^{* * *}$ & $-0,489 * * *$ & $-0,454^{* * *}$ & $-0,486^{* * *}$ & $-0,492^{* * *}$ & $-0,489 * * *$ & $-0,454^{* * *}$ \\
\hline & $(0,0161)$ & $(0,0161)$ & $(0,0164)$ & $(0,0175)$ & $(0,0162)$ & $(0,0161)$ & $(0,0164)$ & $(0,0175)$ & $(0,0160)$ & $(0,0161)$ & $(0,0163)$ & $(0,0175)$ \\
\hline \multirow{2}{*}{$35-39$} & $-0,537^{* * *}$ & $-0,542^{* * *}$ & $-0,537^{* * *}$ & $-0,495^{* * *}$ & $-0,537^{* * *}$ & $-0,543^{* * *}$ & $-0,538^{* * *}$ & $-0,496^{* * *}$ & $-0,536^{* * *}$ & $-0,542^{* * *}$ & $-0,538^{* * *}$ & $-0,496^{* * *}$ \\
\hline & $(0,0161)$ & $(0,0161)$ & $(0,0163)$ & $(0,0175)$ & $(0,0162)$ & $(0,0161)$ & $(0,0164)$ & $(0,0175)$ & $(0,0160)$ & $(0,0161)$ & $(0,0163)$ & $(0,0175)$ \\
\hline \multirow{2}{*}{$40-44$} & $-0,558^{* * *}$ & $-0,563^{* * *}$ & $-0,558^{* * *}$ & $-0,514^{* * *}$ & $-0,558^{* * *}$ & $-0,564^{* * *}$ & $-0,560 * * *$ & $-0,515^{* * *}$ & $-0,557^{* * *}$ & $-0,563^{* * *}$ & $-0,559 * * *$ & $-0,514^{* * *}$ \\
\hline & $(0,0161)$ & $(0,0160)$ & $(0,0163)$ & $(0,0175)$ & $(0,0162)$ & $(0,0161)$ & $(0,0163)$ & $(0,0175)$ & $(0,0160)$ & $(0,0160)$ & $(0,0163)$ & $(0,0175)$ \\
\hline \multirow{2}{*}{$45-49$} & $-0,570^{* * *}$ & $-0,575^{* * *}$ & $-0,571^{* * *}$ & $-0,527^{* * *}$ & $-0,571^{* * *}$ & $-0,576^{* * *}$ & $-0,573^{* * *}$ & $-0,528^{* * *}$ & $-0,569^{* * *}$ & $-0,576^{* * *}$ & $-0,572^{* * *}$ & $-0,528^{* * *}$ \\
\hline & $(0,0160)$ & $(0,0160)$ & $(0,0163)$ & $(0,0175)$ & $(0,0161)$ & $(0,0160)$ & $(0,0163)$ & $(0,0175)$ & $(0,0159)$ & $(0,0160)$ & $(0,0162)$ & $(0,0174)$ \\
\hline \multirow{2}{*}{$50-54$} & $-0,585^{* * *}$ & $-0,590^{* * *}$ & $-0,586^{* * *}$ & $-0,540^{* * *}$ & $-0,586^{* * *}$ & $-0,591^{* * *}$ & $-0,587^{* * *}$ & $-0,541^{* * *}$ & $-0,584^{* * *}$ & $-0,590^{* * *}$ & $-0,587^{* * *}$ & $-0,541^{* * *}$ \\
\hline & $(0,0160)$ & $(0,0160)$ & $(0,0162)$ & $(0,0174)$ & $(0,0161)$ & $(0,0160)$ & $(0,0163)$ & $(0,0175)$ & $(0,0159)$ & $(0,0160)$ & $(0,0162)$ & $(0,0174)$ \\
\hline \multirow{2}{*}{$55-59$} & $-0,595^{* * *}$ & $-0,600^{* * *}$ & $-0,597^{* * *}$ & $-0,550^{* * *}$ & $-0,596^{* * *}$ & $-0,602^{* * *}$ & $-0,598^{* * *}$ & $-0,551^{* * *}$ & $-0,594^{* * *}$ & $-0,601^{* * *}$ & $-0,598^{* * *}$ & $-0,551^{* * *}$ \\
\hline & $(0,0160)$ & $(0,0160)$ & $(0,0162)$ & $(0,0175)$ & $(0,0161)$ & $(0,0160)$ & $(0,0163)$ & $(0,0175)$ & $(0,0159)$ & $(0,0160)$ & $(0,0162)$ & $(0,0174)$ \\
\hline \multirow{2}{*}{$60-64$} & $-0,605^{* * *}$ & $-0,610^{* * *}$ & $-0,607^{* * *}$ & $-0,566^{* * *}$ & $-0,605^{* * *}$ & $-0,612^{* * *}$ & $-0,609^{* * *}$ & $-0,567^{* * *}$ & $-0,604^{* * *}$ & $-0,611^{* * *}$ & $-0,608^{* * *}$ & $-0,567^{* * *}$ \\
\hline & $(0,0162)$ & $(0,0162)$ & $(0,0164)$ & $(0,0176)$ & $(0,0163)$ & $(0,0162)$ & $(0,0164)$ & $(0,0176)$ & $(0,0161)$ & $(0,0162)$ & $(0,0164)$ & $(0,0176)$ \\
\hline \multirow{2}{*}{ Žene } & $0,0176^{* * *}$ & $0,0175^{* * *}$ & $0,0190^{* * *}$ & $0,0135^{* * *}$ & $0,0176^{* * *}$ & $0,0175^{* * *}$ & $0,0190^{* * *}$ & $0,0136^{* * *}$ & $0,0176^{* * *}$ & $0,0174^{* * *}$ & $0,0190^{* * *}$ & $0,0136^{* * *}$ \\
\hline & $(0,00229)$ & $(0,00229)$ & $(0,00228)$ & $(0,00246)$ & $(0,00229)$ & $(0,00229)$ & $(0,00228)$ & $(0,00246)$ & $(0,00229)$ & $(0,00229)$ & $(0,00229)$ & $(0,00246)$ \\
\hline \multirow{2}{*}{$\begin{array}{l}\text { U braku } \\
\text { (kohabitaciji) }\end{array}$} & $-0,0444^{* * *}$ & $-0,0436^{* * *}$ & $-0,0452^{* * *}$ & $-0,0389 * * *$ & $-0,0448^{* * *}$ & $-0,0436^{* * *}$ & $-0,0452^{* * *}$ & $-0,0389^{* * *}$ & $-0,0443^{* * *}$ & $-0,0434^{* * *}$ & $-0,0450^{* * *}$ & $-0,0388^{* * *}$ \\
\hline & $(0,00262)$ & $(0,00261)$ & $(0,00261)$ & $(0,00252)$ & $(0,00262)$ & $(0,00261)$ & $(0,00261)$ & $(0,00252)$ & $(0,00262)$ & $(0,00261)$ & $(0,00261)$ & $(0,00252)$ \\
\hline \multirow{2}{*}{ Stranci } & $0,0326^{* * *}$ & $0,0330^{* * *}$ & $0,0357^{* * *}$ & $0,0242^{* * *}$ & $0,0330^{* * *}$ & $0,0333^{* * *}$ & $0,0360^{* * *}$ & $0,0243^{* * *}$ & $0,0324^{* * *}$ & $0,0331^{* * *}$ & $0,0357^{* * *}$ & $0,0242^{* * *}$ \\
\hline & $(0,00373)$ & $(0,00373)$ & $(0,00376)$ & $(0,00362)$ & $(0,00373)$ & $(0,00373)$ & $(0,00376)$ & $(0,00362)$ & $(0,00373)$ & $(0,00373)$ & $(0,00376)$ & $(0,00362)$ \\
\hline
\end{tabular}




\begin{tabular}{|c|c|c|c|c|c|c|c|c|c|c|c|c|}
\hline \multirow{2}{*}{$\begin{array}{c}\text { Marginalni } \\
\text { učinci } \\
\text { liberalizacije }\end{array}$} & \multicolumn{4}{|c|}{ Obje reformske varijable } & \multicolumn{4}{|c|}{ Kumulativni učinak } & \multicolumn{4}{|c|}{ Samo EPR reforma } \\
\hline & (1) & (2) & (3) & (4) & (1) & (2) & (3) & (4) & (1) & (2) & (3) & (4) \\
\hline \multicolumn{13}{|l|}{$\begin{array}{l}\text { Osnovna škola } \\
\text { i manje (ref.) }\end{array}$} \\
\hline \multirow{2}{*}{ Srednja škola } & $-0,0884^{* * *}$ & $-0,0897^{* * *}$ & $-0,0874^{* * *}$ & $-0,0341^{* * *}$ & $-0,0880^{* * *}$ & $-0,0899^{* * *}$ & $-0,0875^{* * *}$ & $-0,0342^{* * *}$ & $-0,0871^{* * *}$ & $-0,0897^{* * *}$ & $-0,0875^{* * *}$ & $-0,0342^{* * *}$ \\
\hline & $(0,00485)$ & $(0,00487)$ & $(0,00491)$ & $(0,00427)$ & $(0,00485)$ & $(0,00487)$ & $(0,00491)$ & $(0,00427)$ & $(0,00484)$ & $(0,00487)$ & $(0,00492)$ & $(0,00427)$ \\
\hline \multirow{2}{*}{$\begin{array}{l}\text { Više i visoko } \\
\text { obrazovanje }\end{array}$} & $-0,110^{* * *}$ & $-0,112^{* * *}$ & $-0,105^{* * *}$ & 0,00294 & $-0,110^{* * *}$ & $-0,112^{* * *}$ & $-0,105^{* * *}$ & 0,00276 & $-0,108^{* * *}$ & $-0,112^{* * *}$ & $-0,105^{* * *}$ & 0,00300 \\
\hline & $(0,00508)$ & $(0,00509)$ & $(0,00523)$ & $(0,00628)$ & $(0,00507)$ & $(0,00509)$ & $(0,00523)$ & $(0,00628)$ & $(0,00507)$ & $(0,00509)$ & $(0,00523)$ & $(0,00629)$ \\
\hline \multirow{2}{*}{$\begin{array}{l}\text { Urbano mjesto } \\
\text { stanovanja }\end{array}$} & no & no & $-0,00796^{* * *}$ & $-0,00525^{* *}$ & no & no & $-0,00852^{* * *}$ & $-0,00567^{* *}$ & no & no & $-0,00777^{* * *}$ & $-0,00511^{* *}$ \\
\hline & & & $(0,00243)$ & $(0,00236)$ & & & $(0,00242)$ & $(0,00236)$ & & & $(0,00242)$ & $(0,00236)$ \\
\hline Vremenski trend & no & yes & yes & yes & no & yes & yes & yes & no & yes & yes & yes \\
\hline $\begin{array}{l}\text { Stopa rasta BDP- } \\
\text { a (kvartalno) }\end{array}$ & no & yes & yes & yes & no & yes & yes & yes & no & yes & yes & yes \\
\hline $\begin{array}{l}\text { Regionalne } \\
\text { varijable }\end{array}$ & no & no & yes & yes & no & no & yes & yes & no & no & yes & yes \\
\hline $\begin{array}{l}\text { Varijable na } \\
\text { razini poduzeća }\end{array}$ & no & no & no & yes & no & no & no & yes & no & no & no & yes \\
\hline Broj opažanja & 120.666 & 120.662 & 120.662 & 118.433 & 120.666 & 120.662 & 120.662 & 118.433 & 120.666 & 120.662 & 120.662 & 118.433 \\
\hline Log likelihood & $-5,533 e^{06}$ & $-5,527 \mathrm{e}^{06}$ & $-5,479 \mathrm{e}^{06}$ & $-5,130 \mathrm{e}^{06}$ & $-5,542 \mathrm{e}^{06}$ & $-5,530 \mathrm{e}^{06}$ & $-5,482 \mathrm{e}^{06}$ & $-5,132 \mathrm{e}^{06}$ & $-5,541 \mathrm{e}^{06}$ & $-5,528 e^{06}$ & $-5,480 \mathrm{e}^{06}$ & $-5,13 e^{06}$ \\
\hline chi2 & 10142 & 10211 & 10578 & 11657 & 10025 & 10161 & 10536 & 11629 & 10114 & 10218 & 10584 & 11658 \\
\hline $\mathrm{p}$ & 0 & 0 & 0 & 0 & 0 & 0 & 0 & 0 & 0 & 0 & 0 & 0 \\
\hline r2_p & 0,129 & 0,130 & 0,138 & 0,157 & 0,127 & 0,129 & 0,137 & 0,157 & 0,128 & 0,130 & 0,137 & 0,157 \\
\hline
\end{tabular}

Napomene: Detaljnije informacije o probit regresijama, uključujući ostale specifikacije modela, dostupne su na zahtjev. Robusne standardne greške u zagradama. *** $p<0,01,{ }^{* *} p<0,05,{ }^{*} p<0,1$.

Izvor: Izračun autorice na temelju ARS podataka. 
Tablica A3.

Marginalni učinci nakon probit regresija za zapošljavanje (zaposlenici)

\begin{tabular}{|c|c|c|c|c|c|c|c|c|c|}
\hline \multirow{2}{*}{$\begin{array}{l}\text { Marginalni učinci } \\
\text { liberalizacije }\end{array}$} & \multicolumn{3}{|c|}{ Obje reformske varijable } & \multicolumn{3}{|c|}{ Kumulativni učinak } & \multicolumn{3}{|c|}{ Samo EPR reforma } \\
\hline & (1) & (2) & (3) & (1) & (2) & (3) & (1) & (2) & (3) \\
\hline \multirow{2}{*}{$\begin{array}{l}\text { EPT }(2013 m 7- \\
2014 \mathrm{~m} 7)\end{array}$} & $-0,0278^{* * *}$ & 0,000621 & $-0,00152$ & & & & & & \\
\hline & $(0,00430)$ & $(0,00533)$ & $(0,00536)$ & & & & & & \\
\hline \multirow{2}{*}{$\begin{array}{l}\text { EPR (2014m8- } \\
2017 \mathrm{~m} 12)\end{array}$} & $0,0189 * * *$ & $0,0660^{* * *}$ & $0,0676^{* * *}$ & & & & $0,0230 * * *$ & $0,0656^{* * *}$ & $0,0686^{* * *}$ \\
\hline & $(0,00279)$ & $(0,00582)$ & $(0,00586)$ & & & & $(0,00273)$ & $(0,00468)$ & $(0,00472)$ \\
\hline \multirow{2}{*}{$\begin{array}{l}\text { Obje reforme } \\
(2013 \mathrm{~m} 7- \\
2017 \mathrm{~m} 12)\end{array}$} & & & & $0,00702^{* * *}$ & $0,0248 * * *$ & $0,0240 * * *$ & & & \\
\hline & & & & $(0,00255)$ & $(0,00504)$ & $(0,00508)$ & & & \\
\hline \multicolumn{10}{|l|}{ Dob: $15-19$ (ref.) } \\
\hline \multirow{2}{*}{$20-24$} & $0,247^{* * *}$ & $0,248^{* * *}$ & $0,241^{* * *}$ & $0,247^{* * *}$ & $0,247^{* * *}$ & $0,241^{* * *}$ & $0,247^{* * *}$ & $0,248^{* * *}$ & $0,241^{* * *}$ \\
\hline & $(0,0110)$ & $(0,0109)$ & $(0,0110)$ & $(0,0110)$ & $(0,0110)$ & $(0,0110)$ & $(0,0110)$ & $(0,0109)$ & $(0,0110)$ \\
\hline \multirow{2}{*}{$25-29$} & $0,322^{* * *}$ & $0,323^{* * *}$ & $0,306^{* * *}$ & $0,321^{* * *}$ & $0,322^{* * *}$ & $0,305^{* * *}$ & $0,322^{* * *}$ & $0,323^{* * *}$ & $0,306^{* * *}$ \\
\hline & $(0,0107)$ & $(0,0107)$ & $(0,0107)$ & $(0,0107)$ & $(0,0107)$ & $(0,0108)$ & $(0,0107)$ & $(0,0107)$ & $(0,0107)$ \\
\hline \multirow{2}{*}{$30-34$} & $0,338^{* * *}$ & $0,339^{* * *}$ & $0,317^{* * *}$ & $0,337^{* * *}$ & $0,338^{* * *}$ & $0,315^{* * *}$ & $0,338^{* * *}$ & $0,339 * * *$ & $0,317^{* * *}$ \\
\hline & $(0,0108)$ & $(0,0108)$ & $(0,0109)$ & $(0,0108)$ & $(0,0108)$ & $(0,0109)$ & $(0,0108)$ & $(0,0108)$ & $(0,0109)$ \\
\hline \multirow{2}{*}{$35-39$} & $0,334^{* * *}$ & $0,336^{* * *}$ & $0,310^{* * *}$ & $0,334^{* * *}$ & $0,335^{* * *}$ & $0,309^{* * *}$ & $0,334^{* * *}$ & $0,336^{* * *}$ & $0,310^{* * *}$ \\
\hline & $(0,0108)$ & $(0,0108)$ & $(0,0109)$ & $(0,0108)$ & $(0,0108)$ & $(0,0110)$ & $(0,0108)$ & $(0,0108)$ & $(0,0109)$ \\
\hline \multirow{2}{*}{$40-44$} & $0,338^{* * *}$ & $0,340^{* * *}$ & $0,315^{* * *}$ & $0,338^{* * *}$ & $0,339^{* * *}$ & $0,314^{* * *}$ & $0,338^{* * *}$ & $0,339^{* * *}$ & $0,315^{* * *}$ \\
\hline & $(0,0108)$ & $(0,0108)$ & $(0,0109)$ & $(0,0108)$ & $(0,0108)$ & $(0,0109)$ & $(0,0108)$ & $(0,0108)$ & $(0,0109)$ \\
\hline \multirow{2}{*}{$45-49$} & $0,328^{* * *}$ & $0,329 * * *$ & $0,305^{* * *}$ & $0,327^{* * *}$ & $0,328^{* * *}$ & $0,304^{* * *}$ & $0,328^{* * *}$ & $0,329^{* * *}$ & $0,305^{* * *}$ \\
\hline & $(0,0108)$ & $(0,0108)$ & $(0,0109)$ & $(0,0108)$ & $(0,0108)$ & $(0,0109)$ & $(0,0108)$ & $(0,0108)$ & $(0,0109)$ \\
\hline \multirow{2}{*}{$50-54$} & $0,316^{* * *}$ & $0,318^{* * *}$ & $0,291^{* * *}$ & $0,316^{\text {*** }}$ & $0,317^{* * *}$ & $0,290^{* * *}$ & $0,316^{* * *}$ & $0,318^{* * *}$ & $0,291^{* * *}$ \\
\hline & $(0,0108)$ & $(0,0108)$ & $(0,0110)$ & $(0,0108)$ & $(0,0108)$ & $(0,0110)$ & $(0,0108)$ & $(0,0108)$ & $(0,0110)$ \\
\hline \multirow{2}{*}{$55-59$} & $0,274^{* * *}$ & $0,277^{* * *}$ & $0,250^{* * *}$ & $0,274^{* * *}$ & $0,275^{* * *}$ & $0,249^{* * *}$ & $0,274^{* * *}$ & $0,277^{* * *}$ & $0,250^{* * *}$ \\
\hline & $(0,0111)$ & $(0,0111)$ & $(0,0112)$ & $(0,0111)$ & $(0,0111)$ & $(0,0112)$ & $(0,0111)$ & $(0,0111)$ & $(0,0112)$ \\
\hline \multirow{2}{*}{$60-64$} & $0,185^{* * *}$ & $0,188^{* * *}$ & $0,161^{* * *}$ & $0,186^{* * *}$ & $0,187^{* * *}$ & $0,160^{* * *}$ & $0,185^{* * *}$ & $0,188^{* * *}$ & $0,161^{* * *}$ \\
\hline & $(0,0120)$ & $(0,0120)$ & $(0,0121)$ & $(0,0120)$ & $(0,0120)$ & $(0,0121)$ & $(0,0120)$ & $(0,0120)$ & $(0,0121)$ \\
\hline \multirow{2}{*}{ Žene } & $0,0157^{* * *}$ & $0,0158^{* * *}$ & $0,0131^{* * *}$ & $0,0157^{* * *}$ & $0,0158^{* * *}$ & $0,0131^{* * *}$ & $0,0157^{* * *}$ & $0,0158^{* * *}$ & $0,0131^{* * *}$ \\
\hline & $(0,00251)$ & $(0,00251)$ & $(0,00252)$ & $(0,00251)$ & $(0,00251)$ & $(0,00252)$ & $(0,00251)$ & $(0,00251)$ & $(0,00252)$ \\
\hline \multirow{2}{*}{$\begin{array}{l}\text { U braku } \\
\text { (kohabitaciji) }\end{array}$} & $0,0229^{* * *}$ & $0,0220^{* * *}$ & $0,0280^{* * *}$ & $0,0226^{* * *}$ & $0,0222^{* * *}$ & $0,0282^{* * *}$ & $0,0229 * * *$ & $0,0220^{* * *}$ & $0,0280^{* * *}$ \\
\hline & $(0,00305)$ & $(0,00305)$ & $(0,00306)$ & $(0,00305)$ & $(0,00305)$ & $(0,00307)$ & $(0,00305)$ & $(0,00305)$ & $(0,00306)$ \\
\hline Stranci & $-0,0195^{* * *}$ & $-0,0198^{* * *}$ & $-0,0269^{* * *}$ & $-0,0192^{* * *}$ & $-0,0192^{* * *}$ & $-0,0262^{* * *}$ & $-0,0195^{* * *}$ & $-0,0198^{* * *}$ & $-0,0269^{* * *}$ \\
\hline
\end{tabular}




\begin{tabular}{|c|c|c|c|c|c|c|c|c|c|}
\hline \multirow{3}{*}{$\begin{array}{l}\text { Marginalni učinci } \\
\text { liberalizacije }\end{array}$} & \multicolumn{3}{|c|}{ Obje reformske varijable } & \multicolumn{3}{|c|}{ Kumulativni učinak } & \multicolumn{3}{|c|}{ Samo EPR reforma } \\
\hline & (1) & (2) & (3) & (1) & (2) & (3) & (1) & (2) & (3) \\
\hline & $(0,00414)$ & $(0,00414)$ & $(0,00419)$ & $(0,00414)$ & $(0,00414)$ & $(0,00419)$ & $(0,00414)$ & $(0,00414)$ & $(0,00419)$ \\
\hline \multicolumn{10}{|l|}{$\begin{array}{l}\text { Osnovna škola } \\
\text { i manje (ref.) }\end{array}$} \\
\hline \multirow{2}{*}{ Srednja škola } & $0,223^{* * *}$ & $0,224^{* * *}$ & $0,197^{* * *}$ & $0,223^{* * *}$ & $0,224^{* * *}$ & $0,197^{* * *}$ & $0,222^{* * *}$ & $0,224 * * *$ & $0,197 * * *$ \\
\hline & $(0,00398)$ & $(0,00399)$ & $(0,00407)$ & $(0,00398)$ & $(0,00398)$ & $(0,00407)$ & $(0,00398)$ & $(0,00399)$ & $(0,00407)$ \\
\hline \multirow{2}{*}{$\begin{array}{l}\text { Više i visoko } \\
\text { obrazovanje }\end{array}$} & $0,301^{* * *}$ & $0,303^{* * *}$ & $0,260 * * *$ & $0,302^{* * *}$ & $0,302^{* * *}$ & $0,260^{* * *}$ & $0,299 * * *$ & $0,303^{* * *}$ & $0,260^{* * *}$ \\
\hline & $(0,00435)$ & $(0,00436)$ & $(0,00461)$ & $(0,00435)$ & $(0,00435)$ & $(0,00461)$ & $(0,00435)$ & $(0,00436)$ & $(0,00461)$ \\
\hline \multirow{2}{*}{$\begin{array}{l}\text { Urbano mjesto } \\
\text { stanovanja }\end{array}$} & no & no & $0,0529^{* * *}$ & no & no & $0,0511^{* * *}$ & no & no & $0,0529 * * *$ \\
\hline & & & $(0,00266)$ & & & $(0,00265)$ & & & $(0,00266)$ \\
\hline Vremenski trend & no & yes & yes & no & yes & yes & no & yes & yes \\
\hline $\begin{array}{l}\text { Stopa rasta BDP-a } \\
\text { (kvartalno) }\end{array}$ & no & yes & yes & no & yes & yes & no & yes & yes \\
\hline $\begin{array}{l}\text { Regionalne } \\
\text { varijable }\end{array}$ & no & no & yes & no & no & yes & no & no & yes \\
\hline $\begin{array}{l}\text { Varijable na razini } \\
\text { poduzeća }\end{array}$ & no & no & no & no & no & no & no & no & no \\
\hline Broj opažanja & 171.113 & 171.108 & 171.108 & 171.113 & 171.108 & 171.108 & 171.113 & 171.108 & 171.108 \\
\hline Log likelihood & $-1,150 \mathrm{e}^{07}$ & $-1,150 \mathrm{e}^{07}$ & $-1,140 \mathrm{e}^{07}$ & $-1,150 \mathrm{e}^{07}$ & $-1,150 \mathrm{e}^{07}$ & $-1,140 \mathrm{e}^{07}$ & $-1,150 \mathrm{e}^{07}$ & $-1,150 \mathrm{e}^{07}$ & $-1,140 \mathrm{e}^{07}$ \\
\hline chi2 & 7661 & 7777 & 9164 & 7568 & 7602 & 8938 & 7618 & 7776 & 9163 \\
\hline $\mathrm{p}$ & 0 & 0 & 0 & 0 & 0 & 0 & 0 & 0 & 0 \\
\hline r2_p & 0,0469 & 0,0475 & 0,0578 & 0,0462 & 0,0464 & 0,0566 & 0,0466 & 0,0475 & 0,0578 \\
\hline
\end{tabular}

Napomene: Udio zaposlenih čine samo zaposlenici (15-64), ne i samozaposlene osobe i obiteljski radnici. Detaljnije informacije o probit regresijama, uključujući ostale specifikacije modela, dostupne su na zahtjev. Robusne standardne greške u zagradama. ${ }^{* * *} p<0,01,{ }^{* *} p<0,05,{ }^{*} p<0,1$

Izvor: Izračun autorice na temelju ARS podataka. 


\section{Slika A1.}

\section{Rezultati studije događaja na mjesečnoj razini}

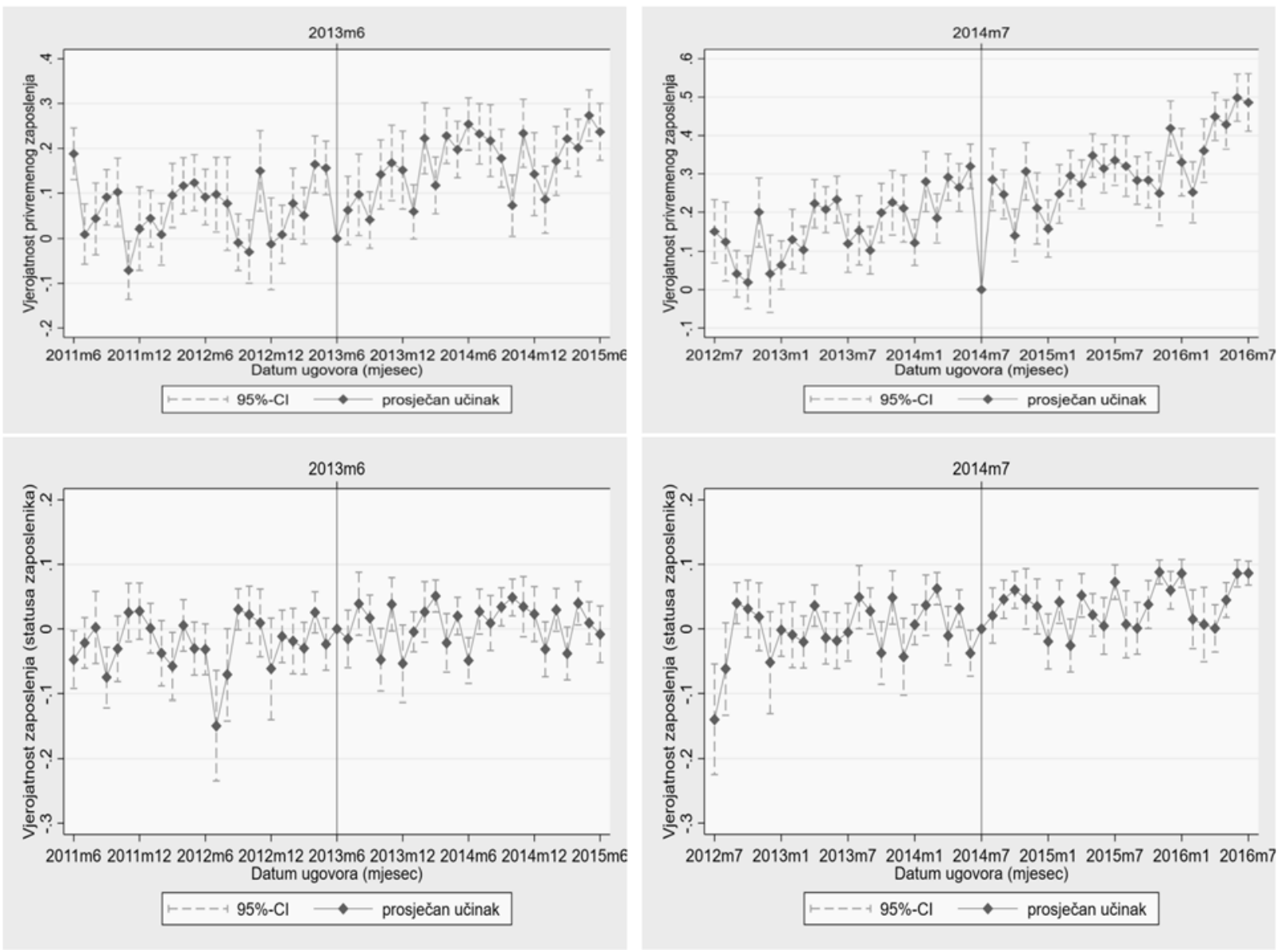

Napomene: Rezultati na temelju linearnog modela vjerojatnosti s robusnim standardnim greškama. Udio zaposlenih čine samo zaposlenici (15-64), ne i samozaposlene osobe i obiteljski radnici. Mjesečni podatci dobiveni su iz godišnjih skupova podataka. U regresijama se kontrolira za osnovni skup individualnih karakteristika, odnosno, dob, spol, bračni status $i$ nacionalnost, plus vremenski trend i kvartalni rast BDP-a. Druge specifikacije modela - poput onih koje uključuju obrazovanje, regiju i razinu urbanizacije - također su testirane i rezultati su manje-više isti (dostupno na zahtjev). Izvor: Izračun autorice na temelju ARS podataka 